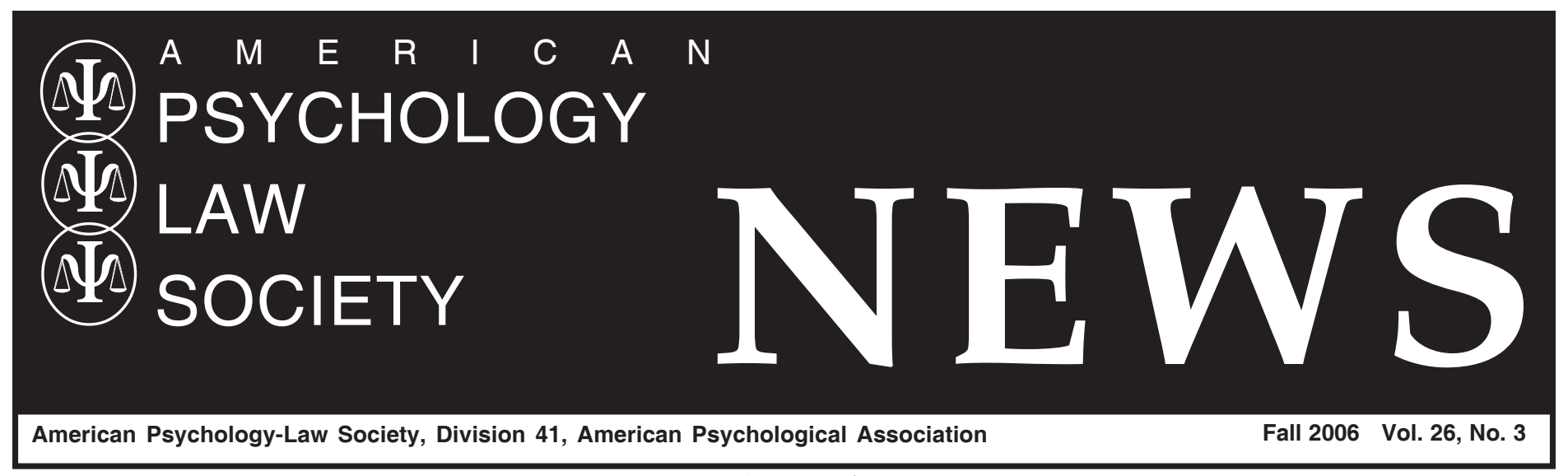

Legal Update

\title{
The Supreme Court Rules on the Insanity Defense and Capital Sentencing Procedures
}

\author{
by David DeMatteo, J.D., Ph.D., Drexel University
}

A previous Legal Update column (Summer 2006, Vol. 26, No. 2) provided a preview of two potentially watershed cases that appeared on the U.S. Supreme Court's 2005-2006 docket. In Clark v. Arizona, the Supreme Court was asked to address (1) whether the U.S. Constitution sets limits on how states define insanity, and (2) whether a state may constitutionally limit consideration of mental health evidence to determinations of insanity and preclude consideration of such evidence in determining whether a defendant could form the requisite criminal intent. This was the first time in over 20 years that the Supreme Court granted certiorari in a case that raised important questions regarding the constitutionality of the insanity defense. In Kansas v. Marsh, the Supreme Court was asked to address the constitutionality of a state statute providing for the mandatory imposition of a death sentence when the sentencing jury determines that aggravating factors and mitigating factors carry equal weight. After a brief recap of Clark and Marsh, this column will summarize the Supreme Court's recent decisions in both cases.

\section{The Insanity Defense - Clark v. Arizona}

In May 2003, Eric Clark stood trial for the June 2000 killing of Flagstaff Police Officer Jeffrey Moritz during a routine traffic stop. Clark suffered from schizophrenia and reportedly believed Flagstaff had been taken over by hostile aliens. At trial, Clark offered two affirmative mental health defenses: guilty except insane and diminished capacity. A guilty except insane verdict is appropriate under Arizona law if an offender, at the time of the crime, was afflicted with a mental disease or defect of such severity that he or she did not know the criminal act was wrong. Clark also sought to present a diminished capacity defense, which would allow the court to find him guilty of a less serious offense if it rejected his insanity defense, but nonetheless concluded that mental illness prevented him from forming the specific intent required for first-degree murder. The trial court ruled that evidence of Clark's mental illness was admissible in relation to his insanity defense, but that Arizona law precluded considering such evidence to negate the mens rea element of the offense (see Arizona v. Mott, 931 P.2d 1046 (Ariz. 1997)).

The trial court rejected Clark's insanity defense, and he was convicted of firstdegree murder and sentenced to 25 years to life. On appeal, Clark argued that (1) Arizona's definition of insanity is unconstitutionally narrow because it does not include the first component of the M'Naghten insanity test (i.e., appreciation of the nature and quality of the act); and (2) Arizona's law prohibiting the consideration of mental health evidence as it relates to whether a defendant had the requisite intent to commit first-degree murder violates the Due Process Clause of the U.S. Constitution. In January 2005, the Arizona Court of Appeals rejected both of Clark's arguments and unanimously affirmed the conviction and sentence. The Arizona Supreme Court subsequently denied Clark’s petition for review.

On June 29, 2006, the U.S. Supreme Court ruled in favor of Arizona by a 5-to-4 vote (Clark v. Arizona, 126 S. Ct. 2709). With respect to the first issue (i.e., Arizona's abbreviated version of the M'Naghten insanity test), the Court held there is no particular formulation of insanity that "has evolved into a baseline for due process" (Clark, 126 S. Ct. at 2722). Although this case presented an opportunity for the Court to establish a constitutional basis for the insanity defense, the Court

\section{Contents...}

Presidential Column 2

Law and Human Behavior Update ...................... 3

Diversity in Psychology and Law ....................... 4

Expert Opinion ...................................................... 6

Research Briefs ................................................. 10

Nominations, Awards, \& Announcements ...... 20

Division News and Information ...................... 22

Calls for Papers and Conferences .................... 26

Student Section ................................................. 28

Fellowships and Positions ............................... 30

Conference/Workshop/Grant Planners ........... 32 Continued on p. 5 


\section{AP-LS News}

Editorial Staff

Editor-In-Chief

Jennifer Groscup, J.D., Ph.D.

jgroscup@jjay.cuny.edu

Production/Advertising Editor

Michele Galietta, Ph.D. galietta13@aol.com

Past Editor-In-Chief

Barry Rosenfeld, Ph.D.

rosenfeld@fordham.edu

Associate Editor, Research Briefs

Marc Boccancini, Ph.D.

PSY_MTB@shsu.edu

Associate Editor, Legal Update

David DeMatteo, J.D., Ph.D.

dsd25@drexel.edu

Associate Editors, Expert Opinion

Matthew Huss, Ph.D, M.L.S.

mhuss@creighton.edu

Eric Elbogen, Ph.D.

eric.elblogen@duke.edu

Website Manager

Adam Fried, M.A.

afried@fordham.edu

The American Psychology-Law Society News is a publication devoted to dissemination of information, news, and commentary about psychology, mental health, and the law. The newsletter is published three times per year; February 1 , June 1, and October 1. Original contributions are welcome, and will be published subject to editorial approval and space availability. A limited amount of space is also available for advertising and unsolicited manuscripts.

For information regarding editorial policies contact the Editor, Jennifer Groscup, Department of Psychology, John Jay College of Criminal Justice, City University of New York, New York, NY 10019 or jgroscup@jjay.cuny. edu. Advertising inquiries should be directed to Michele Galietta, Production Editor, via e-mail: galietta13@ aol.com.

Address changes for APA members should be directed to APA Membership Dept., 750 First St. NE, Washington, DC 20002-4242; for non-APA members, student members, or members-at-large to Lynn Peterson, AP-LS Administrative Assistant at div41apa@comcast.net.

\section{Presidential Column}

\section{An Editorial by Joel Dvoskin, Div. 41 President}

For this edition of the Newsletter, I thought I might try to stir up a little controversy. Let me state my case in short: There is no such thing as an objective expert witness. This is not to suggest that there is no integrity in our business. Some of my AP-LS and AAPL colleagues are among the most honorable, decent, careful, deliberate, and honest people I know. They're just not objective.

The first point in favor of my proposition is that we are human beings. We come to each and every case with pre-existing values, learning histories, experiences, and prejudices, some of which are beyond our awareness. Some of us - not me, thank goodness - are members of political parties. We have different beliefs about social justice, personal responsibility, and the exculpatory effects of poverty, youth, or mental illness.

Second, we do this for a living. (Some of you may cling to the belief that money has no effect on you, but if I paid you enough, I could get you to say that you like Barry Manilow.) Most people are influenced by money. There is no reason to believe that we are exceptions.

Third, most of us want to be praised. There is a plethora of research to support the proposition that people will almost always do more of what brings them praise. To pretend that we are immune to this apparently core human characteristic is selfserving and indefensible.

Fourth, we are biased by the fact that the case gets initially "sold" to us by lawyers, many of whom are skillful and persuasive advocates of their client's point of view.

Fifth, many of us are competitive. Most people prefer to win rather than lose, and it is not by accident that our legal system is called adversarial.

I know that we are not supposed to talk about these things. With a wink and a nod, we all claim to be objective arbiters of wholly truthful opinions, and yet the plain folks who serve on juries are not fooled.
They know that it is never even a challenge to find one of us on either side of each and every question. How is it, they wonder, that lawyers are seemingly never unable to find a psychologist or psychiatrist to have an opinion that helps this particular client?

Recent decisions such as Daubert and Kumho Tire have proposed ostensibly more challenging rules of engagement, to the chagrin of some experts. I feel differently. The reason that Daubert analyses are necessary is because some experts want the courts to "take their word" for things. They want judges and juries to think that they are smart and honest, but most of all right. But why should courts take our word for anything? Our opinions and our psychological tests have error rates, which may or may not be known, and again, there is one of us on either side of the case. In a similar fashion, the Federal Rules of Evidence require us to clearly state the evidence on which our opinions are based.

So what is an expert to do? Some - Alan Stone comes to mind - have argued that maybe we ought to get out of the business altogether. However, courts at every level have rejected this solution, simply because they believe that they need our help. Nor do I believe that these sources of likely bias preclude us from making probative contributions to the legal process.

To that end, I have some suggestions:

1. Transparency — Like good third grade arithmetic students, we should always "show our work." I don't want juries to think that I am smart; I want them to think that they are smart, smart enough to understand the issues posed by the case. I want juries to believe that my findings are so clear and obvious that anyone could have figured them out.

2. As an expert, I am a piece of evidence you know, like a maggot or a fingerprint. (It's not a pretty job, but somebody has to do it.) By presenting information humbly, I invite triers of fact to believe that I am less important than the facts of the case.

Continued on p. 3 


\section{Division 41 - American Psychological Association \\ Law and Human Behavior Updates \\ Brian L. Cutler, Editor-in-Chief}

\section{New Law \& Human Behavior Editorial Board Members}

The editors of Law and Human Behavior express their gratitude to members of the 2006 Editorial Board and the many ad hoc reviewers for their assistance with reviewing manuscripts and facilitating timely feedback to authors. The editors would also like to welcome the following individuals, recently appointed to the 2007 Editorial Board:

David DeMatteo, Department of Psychology, Drexel University

Kevin Douglas, Department of Psychology, Simon Fraser University

Amy Douglass, Department of Psychology, Bates College

Eric Elbogen, Department of Psychiatry, Duke University Medical Center

G. Daniel Lassiter, Department of Psychology, Ohio University

Robert MacCoun, Goldman School of Public Policy and Boalt School of Law, University of California, Berkeley
Randall Salekin, Department of Psychology, University of Alabama

William Thompson, Department of Criminology, Law, and Society, University of California, Irvine

\section{Description of Law and Human Bebavior}

Law and Human Behavior, the official journal of the American Psychology-Law Society/Division 41 of the American Psychological Association, is a multidisciplinary forum for the publication of articles and discussions of issues arising out of the relationships between human behavior and the law, our legal system, and the legal process. This journal publishes original research, reviews of past research, and theoretical studies from professionals in criminal justice, law, psychology, sociology, psychiatry, political science, education, communication, and other areas germane to the field.

AP-LS/Division 41 members receive Law and Human Behavior as part of their membership. To join the American Psychology-Law Society and receive Law and Human Behavior, please visit www.ap-ls.org.
Presidential Column

Continued from $p .2$

3. As an expert, I am also a teacher. If I do my job well, the jury will understand the data and logic upon which I based my inferences, and scrutinize the heck out of them. If I fail in my educational task, they will reject my opinion, and they should.

4. Next, we should take the "whole truth" part of our oath very seriously. I have been testifying as an expert for three decades (give or take) and not once have I worked a case where every single fact or piece of data falls on the same side of the question at bar. Yet I commonly read testimony by mental health experts that is $100 \%$ supportive of the point of view of the attorney who happens to have hired them. Rarely do I see "but see” references to contrary findings in forensic reports, even when there are many contradictory studies in the literature.

5. When reading the reports or depositions of opposing experts, we must force ourselves to consider the possibility that it is they and not us that are correct.

6. At each and every stage of working a case, we should crossexamine ourselves with the same question: "How do I know that?"
7. If you find yourself saying or thinking that you "won" or "prevailed" in a case, seek some peer supervision, because you are out of control.

8. Make sure to turn down or refer cases when you are not an expert. No one is good at everything.

9. Above all, learn the three magic words. (No, it is not appropriate to tell juries that you love them.) The three magic words are "I don't know," and it is the rare expert who will not have an opportunity to say them honestly and often. Whether we take that opportunity, and say those words when they are true, is a measure of our integrity.

Jurors may be unimpressive, but juries are not. The American jury system, in my experience, has a way of elevating groups of people to make much better decisions than they would ever make individually. They know that we don't know everything, even if we seem to have trouble admitting it. Pretending to be totally objective, in my opinion, is not likely to fool anyone.

It is only by acknowledging our blind spots, biases, and prejudices that we can take sensible steps to correct for them.

Joel A. Dvoskin 


\section{Minority Affiars Committee: Diversity in Psychology and Law \\ Roslyn Caldwell, Chair}

\section{*****CONFERENCETRAVELAWARDS*****}

\section{INFORMATION FOR 2007 APPLICATIONS}

\section{PURPOSE OF AWARD}

The Minority Affairs Committee (MAC) was established by the American Psychology-Law Society to facilitate activities and develop opportunities within the Division that embrace, respect and value diversity. More specifically, the purpose of the conference travel awards is to provide financial assistance to students who would like to attend the American Psychological Association's Annual Conference-Division 41 (American Psychology-Law Society) in an effort to increase diversity attendance.

\section{AWARD AMOUNTS}

Three travel awards will be provided: one award in the amount of $\$ 500.00$, and two awards in the amount of $\$ 250.00$ each.

\section{ELIGIBILITY FOR AWARDS}

Current full and part-time undergraduate and graduate students from underrepresented groups may apply. Applicants must be student members of AP-LS with priority given to students presenting at the conference. Underrepresented groups include but are not limited to: racial/ ethnic minorities; first-generation college students; lesbian, gay, bisexual, and transgendered students; and physically disabled students.

\section{APPLICATIONS}

Applications will be awarded on a competitive basis and selected based on the applicant's financial need.

Award applications should contain the following:

1. A cover letter which provides all contact information of the applicant and confirms the applicant's eligibility for the award as a member of an underrepresented group.

2. A three-page (maximum), double-spaced, typewritten application containing the following information:

Discussion of the applicant's benefits of attending and presenting at the conference.

Discussion of the applicant's financial need for the award.

Discussion on how the award will be utilized along with a detailed itemized budget (Award recipients will need to submit financial receipts to the MAC Chair).

\section{APPLICATION SUBMISSION DEADLINE}

Applications must be postmarked by March 16, 2007. Please direct all inquiries to Roslyn M. Caldwell, Ph.D., Minority Affairs Committee Chair, (212) 484-1197 or e-mail: rcaldwell@jjay.cuny.edu

\section{AWARD ANNOUNCEMENTS}

Award recipients will be notified by April 30, 2007. The awards will be presented during the 2007 American Psychological Association Annual Conference for Division 41 in San Francisco, California.

\section{TOAPPLY}

All applicants should submit (5) copies of a cover letter and application to: Roslyn M. Caldwell, Ph.D.

Associate Professor of Psychology John Jay College of Criminal Justice Department of Forensic Psychology The City University of New York 445 W. 59th St., 2124 North Hall New York, NY 10019

\section{Diversity in Psychology Research Award}

\author{
The Minority Affairs Committee would like to announce and congratu- \\ late the 2007 Diversity in Psychology Research Award recipients: \\ Lindsay C. Malloy, M.A., Doctoral Student in Psychology and Social \\ Behavior, University of California, Irvine \\ Research Project: Maltreated Children's Evaluations of the Consequences \\ of Disclosing Negative Events \\ Type of Project: Dissertation \\ Award Amount: $\$ 500.00$ \\ Research Project Advisor: Jodi A. Quas, Ph.D., Associate Professor
}

Samantha Schwartz, M.A, Doctoral Student in Social Psychology, University of Nebraska-Lincoln

Research Project: Effects of a Cultural Relativist Argument on Juror Decision Making in a Sexual Harassment Trial

Type of Project: Master's Thesis

Award Amount: \$1000.00

Research Project Advisor: Jennifer S. Hunt, Ph.D., Assistant Professor

Ny Thi Tran, Undergraduate Student in Psychology, Georgia Southern University

Research Project: Examination of Nullification Instructions and Foreperson Race in Jury Deliberations

Type of Project: Undergraduate Research

Award Amount: \$1000.00

Research Project Advisor: Amy Hackney-Hansen, Ph.D., Associate Professor

Femina P. Varghese, M.A., Doctoral Student in Psychology, Texas Tech University

Research Project: Understanding the Factors that Affect Employability of Soon-to-Be Released Prisoners

Type of Project: Dissertation

Award Amount: \$500.00

Research Project Advisor: Erin E. Hardin, Ph.D., Assistant Professor 


\section{Legal Update, Continued from $p .1$}

reaffirmed that insanity standards are substantially open to state choice. The Court also noted that the legal standards of insanity and the medical definitions of mental abnormality used to support insanity defenses are subject to disagreement. As such, due process does not impose a "single canonical formulation of legal insanity” (Clark, 126 S. Ct. at 2722). Finally, the Court held that Arizona's definition of insanity, despite only including the "right from wrong" component, ostensibly requires consideration of whether the defendant appreciated the "nature and quality" of the act. Specifically, the Court noted that a defendant can establish moral incapacity (i.e., not knowing right from wrong) by demonstrating cognitive incapacity (i.e., not appreciating the nature and quality of the act). This is an important aspect of the Court's decision, because only 20 of the 46 states that permit the insanity defense explicitly mention the "nature and quality" component of the M'Naghten test.

With respect to the second issue, the Court held that Arizona's justifications for limiting consideration of mental health evidence to determinations of insanity (as opposed to mens rea) satisfy due process. The Court noted that Arizona has authority to define its presumption of sanity (i.e., legal capacity) by choosing an insanity standard and placing the burden of persuasion on defendants claiming incapacity. According to the Court, for this authority to be meaningful, Arizona must be allowed to prohibit a defendant from overcoming the sanity presumption more easily when addressing a different issue. In other words, if mental health evidence raised reasonable doubt regarding a defendant's mens rea, an acquittal is required and the issue of insanity would be irrelevant. In this context, the ultimate determination of the defendant's legal capacity would be decided using a less stringent standard (i.e., whether it raised reasonable doubt) as opposed to the more stringent clear and convincing standard required by Arizona law to establish insanity (i.e., legal incapacity). The Court clarified that although a defendant can attempt to rebut the prosecution's evidence of mens rea with other forms of evidence, expert testimony regarding the defendant's mental health is not admissible to negate mens rea.

The Clark decision is contrary to the position taken by the American Psychiatric Association, American Psychological Association, and American Academy of Psychiatry and the Law in a jointly filed amicus curiae brief in support of Clark (Brief Amicus Curiae for the APA et al., 2006). With respect to the first issue, the amici noted there is considerable support from history and current practice for a constitutional rule that precludes punishing an offender who, because of mental illness, lacked rational appreciation of the wrongfulness of his or her conduct when engaging in it. With respect to the second issue, the amici argued that there is a fundamental due process right to present evidence to negate the prosecution's effort to prove the elements of the crime beyond a reasonable doubt.

\section{Capital Sentencing Procedures - Kansas v. Marsh}

After confessing to the 1996 murders of Marry Pusch and her 19month-old daughter in Wichita, Kansas, Michael Marsh was convicted of capital murder and sentenced to death. Pursuant to Kansas statutory law existing at that time, a death sentence was required if a jury unanimously found that aggravating factors were not outweighed by mitigating factors (Kan. Stat. Ann. § 21-4624(e) (repealed 2004)), which is a status referred to as "equipoise." On AP-LS NEWS, Winter 2007 appeal, the Kansas Supreme Court ordered a new trial and held that Kansas's death penalty statute was facially unconstitutional because the equipoise portion violated the $8^{\text {th }}$ and $14^{\text {th }}$ Amendments to the U.S. Constitution (Kansas v. Marsh, 102 P.3d 445 (Kan. 2004)).

On June 26, 2006, a sharply divided (5 to 4) U.S. Supreme Court held that Kansas's capital punishment scheme is constitutional (Kansas v. Marsh, 126 S. Ct. 2516). The Court noted that a prior Supreme Court decision, Walton v. Arizona, 497 U.S. 639 (1990), was controlling. In Walton, the Court held that a state death penalty statute may require the defendant to prove that mitigating factors outweigh aggravating factors. As such, the Court concluded that Kansas is constitutionally permitted to require the imposition of the death penalty when the State has proved beyond a reasonable doubt that mitigating factors do not outweigh aggravating factors, including where the two are in equipoise. According to the Court, even if Walton is not controlling, Kansas's death penalty scheme is consistent with the principles articulated in the Court's death penalty jurisprudence (e.g., Furman v. Georgia, 408 U.S. 238 (1972); Gregg v. Georgia, 428 U.S. 153 (1976)) because it narrows the class of persons eligible for the death penalty and permits individualized sentencing through consideration of mitigating factors. In a vigorous dissent, Justice Souter argued that Kansas's equipoise provision violates the $8^{\text {th }}$ Amendment because it requires the death penalty to be imposed when there is equivocal evidence and, therefore, does not "identify the worst of the worst” (Marsh, 126 S. Ct. at 2543).

The Marsh decision is consistent with the position taken by the Criminal Justice Legal Foundation (CJLF) in an amicus curiae brief filed in support of Kansas (Brief Amicus Curiae of the CJLF, 2005). The CJLF argued that Kansas's death penalty scheme is constitutional because the formula for reaching a sentencing determination is exclusively a matter of state law. According to the CJLF, as long as a defendant is permitted to present mitigating evidence to the jury, how that evidence is considered is a matter of state law. In Marsh, the Supreme Court agreed with this argument, and also held that the U.S. Constitution does not require formal "weighing" of aggravating and mitigating factors (versus simply considering those factors). As such, the death penalty schemes in those states that do not require any formal weighing of aggravating and mitigating factors (e.g., Georgia, Louisiana, South Carolina, South Dakota, Texas, Virginia, Washington) appear to be safe from constitutional scrutiny on those grounds.

\section{References}

Arizona v. Mott, 931 P.2d 1046 (Ariz. 1997).

Brief Amicus Curiae for the American Psychiatric Association, American Psychological Association, and American Academy of Psychiatry and the Law Supporting Petitioner, Clark v. Arizona, 2006 U.S. S. Ct. Briefs Lexis 185 (Jan. 30, 2006) (No. 05-5966).

Brief Amicus Curiae of the Criminal Justice Legal Foundation in Support of Petitioner, Kansas v. Marsh, 2005 U.S. S. Ct. Briefs LEXIS 544 (August 15, 2005) (No. 04-1170).

Clark v. Arizona, 126 S. Ct. 2709 (2006).

Furman v. Georgia, 408 U.S. 238 (1972).

Gregg v. Georgia, 428 U.S. 153 (1976).

Kansas v. Marsh, 126 S. Ct. 2516 (2006).

Kansas v. Marsh, 102 P.3d 445 (Kan. 2004).
Page 5 


\section{Expert Opinion \\ Editors: Matthew Huss \& Eric Elbogen}

\section{Determinations of Dangerousness: Roles and Responsibilities Robert F. Schopp, J.D., Ph.D., Ph.D. University of Nebraska-Lincoln}

John and Mary Smith are clinical psychologists. Their ten year-old daughter Sally comes home from school one day very excited. She says "I found an exciting new game; can I try it just once?" John responds "maybe Sally; do you know the name of the game?" Sally responds - "Yes! Russian Roulette; it’s really exciting!” John says “ No! That's dangerous!” Sally responds - "but daddy; you can’t say Russian Roulette is dangerous; five out of six of your predictions would be false positives.” John responds, “don't talk back to your father; I'm the parent here.”

Suppose, however, that a similar question arises in a different context. Sally is in an auto accident in which she suffers severe spinal injury resulting in quadriplegia. The physicians inform John and Mary that there is an experimental surgery that produces full recovery in five out of six cases. Unfortunately, one patient in six dies during the surgery. John and Mary must decide whether to consent to the surgery for Sally. They have no doubt that this surgery is dangerous, but is it dangerous enough to justify depriving Sally of the opportunity to recover mobility?

There is no obviously correct decision for John and Mary in this case. It would be perfectly consistent and defensible for them to decide that one chance in six of a lethal outcome is much too dangerous to allow Sally to play Russian Roulette but not sufficiently dangerous to justify them in refusing the surgery to relieve Sally of quadriplegia. These decisions illustrate two properties of dangerousness. First, determinations of dangerousness are not predictions. They are estimates of risk in the circumstances and judgments that this risk is sufficient to justify a particular decision. Second, in the context of informal decision making, dangerousness is not a dichotomous property. A person, action, or circumstance might vary along a continuum of dangerousness from slightly dangerous to extremely dangerous. When used as a criterion, however, dangerousness constitutes a threshold determination in that the decision maker must decide that a particular person, action, or circumstance does, or does not, present risk sufficient to justify a particular decision. This requirement of a threshold determination is particularly cogent in legal institutions designed to protect individual liberties and to discipline the exercise of coercive state intervention. A court must determine that the risk presented is, or is not, sufficient to justify the intervention or liability at issue in this case.

This determination requires an estimate of the probability and severity of risk in the circumstances, as well as consideration of the applicable risk management strategies and the available alternatives. It also requires the justificatory judgment that the risk presented is sufficient to justify the particular legal liability or intervention at issue. Just as John and Mary might reasonably conclude that one chance in six of a lethal outcome is sufficient to preclude Russian Roulette but not to preclude potentially curative surgery, a court might reasonably conclude that a particular estimate of risk in specified circumstances is sufficient to fulfill a criterion of dangerousness for a particular legal liability or intervention but not sufficient to fulfill a criterion of dangerousness for a different legal purpose.

Consider, for example, an individual with a history of assaultive behavior associated with persecutory delusions. He has been diagnosed with a chronic schizophrenic disorder. During periods of active psychosis, he has experienced threatening auditory hallucinations, and he has assaulted innocent individuals he identified as the source of these threats. When participating in appropriate treatment, his hallucinations and delusions abate, and he manifests no assaultive or threatening behavior. A court might reasonably conclude that he is dangerous for the purpose of outpatient commitment to a monitored treatment program and that as long as he participates in that program, he is not dangerous for the purpose of inpatient commitment.

As psychologists in clinical practice, the Smiths might be asked to assess individuals for the purpose of making a determination of dangerousness in a variety of contexts. Consider first, an assessment of risk for the purpose of testimony at a civil commitment hearing. Mary Smith evaluates Anderson for current impairment and risk for the purpose of commitment under a statute requiring dangerousness due to mental illness. Mary can provide assessment of risk in the current circumstances and in various alternative circumstances involving treatment of various types in either outpatient or inpatient settings. Descriptive and explanatory testimony regarding the probability and severity of risk Ander- 
son presents in various circumstances, the relationship between that risk and his impairment, and the likely effects of various forms of treatment or risk management all fall within the range of expertise when appropriate information is available.

Expert testimony that Anderson is or is not dangerous due to mental illness would be inappropriate, however, because it would require two types of inferences that fall outside the bounds of psychological expertise. First, it would entail the justificatory judgment that the risk involved was sufficient to justify the intrusion into legally protected liberty inherent in commitment. Second, it would entail the justificatory judgment that the risk presented was related to the Anderson's impairment in a manner that justifies the conclusion that this dangerousness is associated with his mental illness in a manner that justifies commitment. Although Mary might provide relevant testimony regarding both of these inferences, she cannot offer a clinical opinion that either inference is, or is not, established because those determinations require justificatory judgments that fall within the scope of the court's responsibility, rather than within professional expertise.

Alternately, suppose that Anderson is currently on an inpatient ward pursuant to a civil commitment order based on a prior judicial determination that he is dangerous due to mental illness. As the severity of his impairment ameliorates due to ongoing treatment, he no longer engages in any aggressive or threatening behavior. As this pattern of improved functioning continues, the psychologists who manage the inpatient treatment program make a series of decisions regarding Anderson's eligibility to participate in a progression of less restrictive treatment plans involving, for example, off-ward privileges, home visits, and then conditional release to an outpatient treatment program. In contrast to Mary Smith who testified in court at the commitment hearing, these clinicians are charged with the responsibility to decide that Anderson has, or has not, progressed to the point that the risk he presents is sufficiently ameliorated to justify a decrease in the level of restraint and monitoring. Thus, the justificatory judgments that are made by the court in the context of the commitment hearing are delegated to the treatment clinicians in the context of the ongoing program of treatment, monitoring, and risk management.

In making these judgments that Anderson has progressed to the point that renders appropriate less restrictive and less closely monitored treatment conditions, the clinicians combine their clinical expertise with unavoidably justificatory judgments regarding the degree and severity of risk that justifies various treatment modalities, levels of supervision, and forms of risk management. When clinicians are charged with the responsibility to make such decisions regarding a particular individual, they must apply their clinical expertise in assessing that individual's clinical condition and the risk he presents under a variety of available circumstances. The decision that the individual's current clinical condition and available treatment alternatives render appropriate the modification of treatment and risk management approaches by moving the individual to a more or less restrictive setting unavoidably involves justificatory judgments that extend beyond the boundaries of clinical expertise. Regardless of whether these judgments are explicitly articulated, they involve the degree of risk that justifies lesser or greater intrusion into liberty as well as the most defensible distribution of that risk among the individual and all those with whom he will come into contact in any of the selected circumstances. Clinicians who recognize the justificatory components of these decisions explicitly confront and attempt to address these justificatory questions. Those who do not recognize these justificatory components undermine their own ability to make these decisions in a responsible manner.

This concern regarding the most defensible distribution of risk further complicates decisions regarding treatment and disposition when they must be made in the common circumstances of limited resources. This concern is clearly illustrated in the context of sexual predator commitment. When a court or a clinician evaluates a convicted sex offender for the purpose of initiating or continuing a sexual predator commitment following the completion of the criminal sentence, it may seem reasonable to conclude that any offender who presents any risk of committing further sexual offenses presents risk sufficient to justify ongoing commitment of the guilty offender in order to protect the innocent victims of further offenses. Arguably, this judgment is frequently made because experience with the application of these statutes reveals that very few offenders committed under sexual predator commitment provisions are released. Insofar as the resources for commitment are finite, however, the determination that this particular offender remains dangerous enough to justify ongoing commitment unavoidably raises the question whether this offender presents risk sufficient to justify continued application of these resources to this offender rather than to other offenders, or to alternative programs or strategies. Although clinicians or judges often make such determinations, they frequently lack the broader array of information that would be relevant to such comparative decisions.

Recall John Smith's decisions about Sally's request to play Russian Roulette and about her surgery. Regarding both decisions, John had access to the relevant information about the positive and negative value of the likely outcomes, and he occupied the role of a parent who legitimately exercised the authority to make decisions regarding his young child. The second decision was much more difficult than the first 


\section{Continued from $p .7$}

because the potential trade-off of risk and benefit was very troubling. Thus, John was confronted with the difficult justificatory decision regarding whether the potential therapeutic benefits justified subjecting Sally to the risk of lethal outcome.

When Mary Smith was called upon to testify in Anderson's civil commitment hearing, the institutional structure of the court allocated to Mary the responsibility to apply her psychological expertise in the form of assessment and testimony regarding diagnosis and regarding empirical matters addressing risk assessment and management. That institutional structure allocated to the court the responsibility to make the justificatory decision that Anderson's risk and psychological impairment are, or are not, sufficient to justify civil commitment. Either Mary or the judge might not recognize the boundary between the empirical matters that fall within Mary's range of expertise and responsibility and the justificatory decisions that fall within the judge's range of expertise and responsibility. Insofar as either or both do not recognize this allocation of responsibility, they increase the probability that Mary will unwittingly offer, or be called upon to offer, her legal opinion in the form of justificatory judgments that violate the boundaries of her role as an expert witness.

The clinicians who make decisions about Anderson's treatment, level of supervision, and disposition after his commitment combine clinical judgments that fall within their expertise with justificatory judgments that are delegated to them in their role as treatment providers. Their range of responsibilities extends to justificatory judgments that are beyond Mary's range of responsibilities not because their expertise differs from Mary's but because the institutional structures allocate responsibilities differently to psychologists in the roles of treatment providers and expert witnesses. In each role, psychologists' ability to fulfill responsibilities depends partially upon their care and expertise, but it also depends partially on accurate recognition by the clinical and legal actors of the appropriate allocation of responsibilities in each professional role.

In the content of commitment hearings, judges who recognize the distribution of responsibilities elicit descriptive and explanatory testimony from Mary and reserve justificatory decisions for juries or themselves. Judges who do not recognize the distinct empirical and justificatory components of dangerousness may look to psychological experts for putatively expert opinions that individuals are, or are not, dangerous. Psychologists in these circumstances can explain that they can provide expert testimony regarding the risk in the circumstance but that the decision that this risk is sufficient to justify commitment extends beyond the bounds of professional expertise. Some judges may accept this explanation, but others will not. The latter judges may ask witnesses for expert opinions that individuals are, or are not, dangerous. In these circumstances, psychologists face difficult decisions either to explicitly state that they have no expert opinion regarding that question or to offer their personal opinion that the risk is, or is not, sufficient to justify commitment. The latter approach may be a defensible practical decision in some circumstances. Insofar as individual psychologists take this approach, however, they are more likely to make responsible justificatory decisions if they explicitly recognize that this is the responsibility they have chosen to discharge.

Similarly, psychologists providing treatment in inpatient or outpatient contexts sometimes encounter circumstances in which they face delegated responsibilities to make judgments regarding dangerousness for the purpose of moving a committed patient to less closely supervised treatment conditions or for the purpose of taking steps to protect third parties in Tarasoff-type conditions. In these circumstances, psychologists combine professional assessment of risk with justificatory judgments that this risk is, or is not, sufficient to justify decisions involving increased or decreased freedom or disclosure of information intended to protect third parties. By explicitly recognizing the justificatory nature of these delegated decisions, psychologists enhance their ability to responsibly consider morally and legally relevant considerations such as generally accepted practices in the profession, available risk management practices, and the social value of various interests at stake for all the parties at risk.

Extended discussion of these concerns can be found in the following publications by the author:

Competence, Condemnation, and Commitment (American Psychological Association, 2001) Chapters 10-12.

Outpatient Civil Commitment, 9 Psychology, Public Policy, and Law 33 (2003).

Two-Edged Swords, Dangerousness, and Expert Testimony in Capital Sentencing, 30 Law \& Psychology Review 57 (2006).

\section{Book and Test Reviews}

Written (or read) a new book you want reviewed ? A psychological test that you want readers to know about? Recommendations for books, tests, or other media that you would like to see reviewed in the APLS News should be forwarded to Jennifer Groscup, (jgroscup@jjay.cuny..edu). Offers to review the work of others, or recommendations as to who an appropriate review might be for your own work are always appreciated. 


\section{Jiugit pafiessional Ljabillity Insurance*}

"It's simply the best, better

than all the rest! Call the Trust today

to find out why I and 40,000 of my colleagues, ‘..put our Trust where it belongs!"

\section{It's not just an insurance policy!}

When you buy from the Trust, you get much more than just an insurance policy. A Risk Management Program is at your fingertips!

- Internet access to your policy anytime

- Free Advocate 800 Risk Management

Consultation Service for any Trust Insured

- CD-ROM Ethics and Risk Management

Instructional Series, CE Credits, great rates and big discounts

- HIPAA Compliance Resources

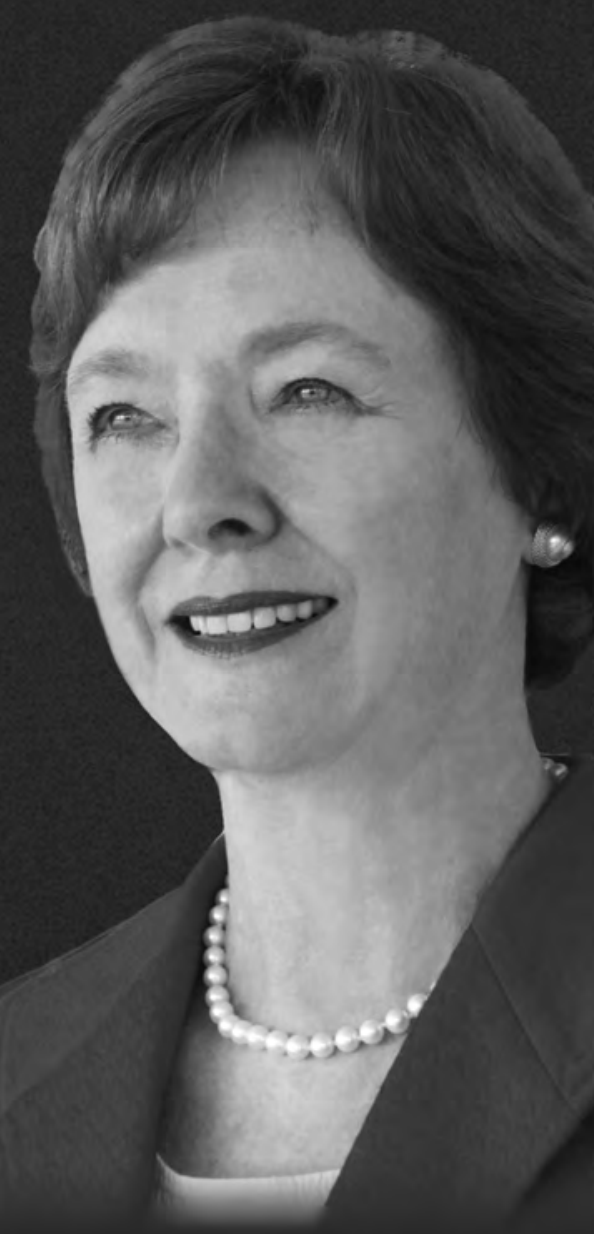

Carol D. Goodheart, Ed.D., is a Trustee of the APA Insurance Trust. She is the APA Treasurer, an ex-officio member of the Committee for the Advancement of Professional Practice (CAPP), a Past President of Division 42 (Independent Practice), and a Fellow of APA.

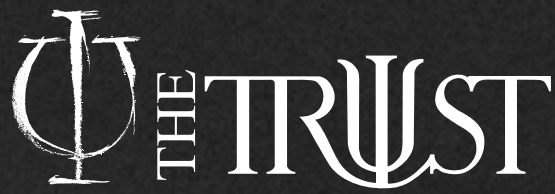

\section{1-800-477-1200 (Phone) • 1-800-477-1268 (Fax) www.apait.org}

* Underwritten by ACE American Insurance Company, one of the ACE USA companies. ACE USA is the U.S.-based retail operating division of the ACE Group of Companies rated A+, by A.M. Best. ** Administered by Trust Risk Management Services. 


\section{CORRECTIONAL}

Cloyes, K.G., Lovell, D., Allen, D., \& Rhodes, L.A. (2006). Assessment of psychosocial impairment in a supermaximum security unit sample. Criminal Justice and Behavior, 33, 760-781. The Brief Psychiatric Rating Scale (BPRS) was found to be predictive of psychosocial functioning in super-maximum security inmates $(N=87)$.

Hiller, M. L., Knight, K., Saum, C.A., \& Simpson, D.D. (2006). Social functioning, treatment dropout, and recidivism of probationers mandated to a modified therapeutic community. Criminal Justice and Behavior, 33, 738-759. The research team examined changes in social functioning during the first 90 days of treatment in a therapeutic community for 406 probationers. Improvements associated with treatment included decreased risk taking and increased social functioning.

Raney, V.K., Magaletta, P., \& Hubbert, T. A. (2005). Perception of helpfulness among participants in a prison-based residential substance abuse treatment program. Journal of Offender Rehabilitation, 42, 25-34. Incarcerated adult males $(N=87)$ in a residential drug abuse program who perceived themselves as eligible for early release identified significantly more life skills (e.g., drug awareness, financial responsibility) they wanted to acquire than those who perceived themselves as ineligible. Individuals with 6 months of participation saw treatment as more helpful than those with 1 or 3 months of participation, and they were more satisfied than those with 3 months of participation.

Skogstad, P., Deane, F.P., \& spicer, J. (2005). Barriers to (4) Page 10

\section{Research Briefs}

\section{Editor: Marc Boccancini, Ph.D.}

The AP-LS newsletter research briefs are written by students in the Clinical Psychology Ph.D. Program at Sam Houston State University. Contributors for this year are: Beth Caillouet, Jeremy Johnson, Lisa Kan, Kristy Lawson, and Amanda McGorty

helpseeking among New Zealand prison inmates. Journal of Offender Rehabilitation, 42, 1-24. Male inmates $(N=52)$ with previous contact with prison psychologists had a more positive general attitude toward psychological help-seeking than those without such contact. These attitudes were positively related to seeking help for personalemotional problems and for suicidal feelings. Suicidal ideation, however, was negatively correlated with help-seeking intentions for suicidal feelings. Previous contact and psychological distress were unrelated to any help-seeking intention.

Smith, S., \& Ferguson, N. (2005). Getting clean in a drug rehabilitation program in prison: A grounded theory analysis. Journal of Offender Rehabilitation, 42, 51-74. Content analysis of semistructured interviews with 11 male inmates in a drug rehabilitation program produced five themes related to the inmates' reasons for enrolling in the program: addiction history, motivation for treatment, vulnerabilities to relapse, strategies to remain abstinent, and perceptions of the recovery process.

Spiropoulous, G.V., Spruance, L., Van Voorhis, P., \& Schmitt, M.M. (2005). Pathfinders and problem solving: Comparative effects of two cognitive-behavioral programs among men and women offenders in community and prison. Journal of Offender Rehabilitation, 42, 69-94. Community members and inmates participating in Problem Solving, a cognitivebehavioral program for impulsivity, experienced significantly greater reductions in depressive symptoms than non-participants, except for incarcerated female participants; their depressive symptoms reduced only when they also participated in Pathfinders. Problem Solving was associated in significantly less disciplinary infractions for community and incarcerated female participants, and incarcerated male participants reported less conflictual behaviors.

Walters, G.D. (2006). Effect of test administration set on the Psychological Inventory of Criminal Thinking Styles (PICTS). International Journal of Offender Therapy and Comparative Criminology, 50, 661-671. The PICTS was administered to male prisoners $(N=160)$ who were then assigned to a psychological treatment group $(n=54)$ or a control group $(n=106)$. Inmates in the treatment group were more likely to endorse PICTS items and were less defensive than non-treatment inmates after a follow-up period of six months.

White, M.D., \& Hallett, M. (2005). Revisiting anomalous outcome data from the “Breaking the Cycle” pro- gram in Jacksonville. Journal of Offender Rehabilitation, 42, 1-22. Among participants in a drug treatment supervision program $(N=200)$, rearrest rates were highest for those who were not released pretrial, were 30 years old or younger, had not completed high school, and/or had prior arrests. Program participation was a non-significant predictor of rearrest after accounting for group differences in ethnicity, pretrial release status, and type of current charge.

\section{DELIQUENCY/ANTISO- CIALBEHAVIOR}

Barker, E.D., Tremblay, R.E., Nagin, D.S., Vitaro, F., \& Lacourse, E. (2006). Development of male proactive and reactive physical aggression during adolescence. Journal of Child Psychology and Psychiatry, 47, 783-790. Inner city boys ages $13-17(N=1037)$ provided self reports of reactive and proactive aggression. Data analysis was used to identify groups of boys with similar characteristics. The three groups identified included one with near zero levels of both PA and RA, one with initial moderate levels of both, and a group that peaked at a high level of both.

Banyard, V.L., Cross, C., \& Modecki, K.L. (2006). Interpersonal violence in adolescence: Ecological correlates of self-reported perpetration. Journal of Interpersonal Violence, 21, 1314-1332. Adolescents aged 11-19 ( $N=980)$ were surveyed regarding physical dating violence and sexual abuse. Substance use, low social responsibility, low parental monitoring, low social support, low school attachment, and low neighborhood monitoring were correlated with self-reported perpetration.

AP-LS NEWS, Winter 2007 
Caldwell, M., Skeem, J., Salekin, R., \& Rybroek, V. G. (2006). Treatment response of adolescent offenders with psychopathy features: A 2 year follow-up. Criminal Justice and Behavior, 33, 571-596. A sample of youthful male offenders $(N=141)$ who scored above 26 on the PCL:YV were divided into two groups. The first group ( $n=56)$ went to the Mendota Juvenile Treatment Center for intensive treatment and the second group ( $n=85$ ) was given treatment as usual at juvenile correction institutions. Those in the treatment as usual group were twice as likely as those in the Mendota group to be rearrested for a violent crime within two years of treatment.

Caldwell, R.M., Sturges, S.M., Silver, R.C., Brinson, J., DenbyBrinson, R., \& Burgess, K. (2006). An Examination of the influence of perceived parenting practices on depression and substance use among African American juvenile offenders. Journal of Forensic Psychology Practice, 6, 31-50. Depression scores in a sample of 119 adjudicated African American adolescents were negatively correlated with the adolescents' perceptions of maternal roles $(r=-.34)$ and paternal roles ( $r=-$ .35). Severity of substance abuse was negatively correlated with perceptions of paternal roles ( $r=-.35)$.

Essau, C.A., Sasagawa, S., \& Frick, P J. (2006). Callous-unemotional traits in a community sample of adolescents. Assessment, 13, 454-469. Factor analyses of the Inventory of Callous-Unemotional Traits (ICU) revealed that a three-factor model (Callousness, Uncaring, and Unemotional) in which the factors were loaded on a general Callous-Unemotional dimension provided the best fit for data from 1443 adolescents (774 boys, 669 girls). Higher Callousness and lower Unemotional scores predicted problematic behaviors for both genders, while higher Uncaring scores only predicted problematic behaviors in boys. ICU total and factor scores were generally negatively correlated with Big Five personality dimensions.

Huss,M.T., \& LanghinrichsenRohling, J. (2006). Assessing the generalization of psychopathy in a clinical sample of domestic violence perpetrators. Law \& Human Behavior, 30, 571-586. Four clusters of male batterers $(N=131)$ were identified using the MCMI-III Antisocial, Dependent and Depressive scales, and measures of partner and general violence. Cluster membership was positively correlated with PCL:SV total and Factor 2 scores.

Larden, M., Melin, L., Holst, U., \& Langstrom, N. (2006). Moral judgment, cognitive distortions and empathy in incarcerated delinquent and community control adolescents. Psychology, Crime \& Law, 12, 453-462. Swedish adolescents (age: 13-18; 58 delinquents, 58 matched controls) completed questionnaires about moral reasoning, cognitive distortions, and empathy. Delinquent adolescents were less developed in moral reasoning and had more antisocial cognitive distortions than controls; no differences were noted for empathy. Overall, girls reported more developed moral reasoning, fewer cognitive distortions, and more empathy than boys.

Mullins-Nelson, J.L., Salekin, R.T., \& Leistico, A.R. (2006).

Psychopathy, empathy, and perspective-taking ability in a community sample: Implications for the successful psychopathy concept. Interna- tional Journal of Forensic Mental Health, 5, 133-149. The relationship between psychopathy and empathy was explored in a community sample of 174 undergraduates (75\% female). Psychopathy was negatively correlated with perspective-taking and affective components of empathy. Higher psychopathy scores were related to higher levels of antisocial behavior, and deficits in empathy were associated with behavioral components of psychopathy.

Murray, J., Janson, C., \& Farrington, D.P. (2006). Crime in adult offspring of prisoners: Across-national comparison of two longitudinal samples. Criminal Justice and Behavior, 34, 133-149. The relation between parental incarceration and delinquency in their children was examined in two longitudinal community samples, one from England ( $N=411)$ and one from Sweden ( $N=15,117)$ were compared. In the English sample, parental incarceration was found to predict boys' delinquency even after controlling for their parents' criminal and risk level of the boys. In the Swedish sample, controlling for parent criminality significantly reduced the relation between parental incarceration on delinquency.

Sullivan, E.A., Abramowitz, C.S., Lopez, M., \& Kosson, D.S. (2006). Reliability and construct validity of the Psychopathy Checklist-Revised for Latino, European American, and African American Inmates. Psychological Assessment, 18, 382-392. Reliability coefficients for PCL-R total scores were comparable across Latino, European American, and African American adult male inmates $(N=249)$. African Americans scored significantly higher than Latinos on the total and affective facet scores and than higher than European Americans on the total scores. No significant PCL-R by Ethnicity interactions were observed for predicting psychopathology or antisocial behavior.

Walters, G.D. (2006). Proactive and reactive composite scales for the Psychological Inventory of Criminal Thinking (PICTS). Journal of Offender Rehabilitation, 42, 23-36. Analyses of archival data indicated that the PICTS Proactive and Reactive composite scales generally had higher test-retest reliability and were more highly correlated with crime-related variables, psychopathology, and prison adjustment than the PICTS thinking style, factor, and content scales. Evidence also suggested that the composite scales provided general indices of criminal thinking.

Wiebe, R. (2006). Using an expanded measure of self-control to predict delinquency. Psychology, Crime \& Law, 12, 519-536. Undergraduates (90 male, 107 female) answered questions about personality, attitudes, and delinquency. Diligence and neutralizing guilt were added to traditional traits of low self-control to predict self-reported delinquent acts. Risk-seeking, diligence, and neutralization predicted delinquency best. A later study of high schoolers $(N=1139)$ revealed similar results, with risk-seeking, temper, selfishness, diligence, and neutralization contributing in addition to demographic variables.

Wilson, M. \& Daly, M. (2006). Are juvenile offenders extreme future discounters? Psychological Science, 17, 989-994. Teenage participants (91 offenders; 284 high school students) participated in a Page 11 
computerized choice game (small sum tomorrow or larger sum later) with a potential monetary prize and made ratings about future milestones and sensation-seeking. Offenders differed from a high school comparison group in some areas (higher sensationseeking, poorer family statistics), but did not differ significantly on future discounting or estimating milestones.

Young, S. \& Gudjonsson, G.H. (2006). ADHD symptomatology and its relationship with emotional, social and delinquency problems. Psychology, Crime \& Law, 12, 463-471. ADHD ( $n=83)$, Clinical Control ( $n=64)$, and Community Control $(n=33)$ adults completed measures of affect and antisocial behavior measures. ADHD adults reported lower levels of socialization and higher levels of depression, anxiety, and antisocial behavior than either of the control groups.

Zolondek, S., Lilienfeld, S.O., Patrick, C.J., \& Fowler, K.A. (2006). The Interpersonal Measure of Psychopathy: Construct and incremental validity in male prisoners. Assessment, 13, 470482. The Interpersonal Measure of Psychopathy (IM-P) was significantly correlated with the PCL-R total and Factor 1 scores among 93 incarcerated adult males; its correlation with Factor 2 became nonsignificant after controlling for its relationship to Factor 1. The IM-P was not related to the diagnosis of Antisocial Personality Disorder and did not improve the prediction of antisocial behaviors beyond PCL-R total and Factor 1 scores.

\section{DIVERSIONAND COMMU- NITYTREATMENT}

Bowen, E. \& Gilchrist, E. (2006). Predicting dropout of court-mandated treatment in

Page 12 a British sample of domestic violence offenders. Psychology, Crime \& Law, 12, 573-587. Male domestic violence offenders $(N=120)$ were assessed prior to court-ordered to treatment. Those who completed treatment $(n=81)$ were younger at the time of treatment and younger at first offense than non-completers. Predictors of attrition included previous custody, age, and reported physical abuse.

Hartford, K., Carey, R., \& Mendonca, J. (2006). Pre-arrest diversion of people with mental illness: Literature review and international survey. Behavioral Sciences and the Law, 24, 845-856. Representatives from 54 international police departments participating in pre-arrest diversion programs for persons with mental illness completed a survey about the structure of their programs. Program implementation, cost, and outcomes varied across departments, although most departments (70.4\%) provided officers with mental health training. Common diversion services included crisis intervention, case management, and substance abuse treatment.

Kalich, D.M., \& Evans, R.D. (2006). Drug court: An effective alternative to incarceration. Deviant Behavior, 27, 569-590. Persons referred to drug court ( $N=496)$ were separated into 6 groups (graduated form program, active in program, terminated from program, administrative opt out, client opt out and eligible but chose not to participate [control]). Graduates had the lowest rate of rearrest within one year (49.2\%) as compared to $78.6 \%$ of controls and $95.6 \%$ of terminations.

Moore, M.E. \& Hiday, V.A. (2006). Mental health court outcomes: Acomparison of re- arrest and re-arrest severity between mental health court and traditional court participants. Law and Human Behavior, 30, 659-674. Defendants participating in a mental health court (MHC) $(n=82)$ or traditional criminal court (TCC) $(n=183)$ were compared on completion of sentence, prior criminal record, severity of key arrest offense, and rate and severity of re-arrests over a 12month period. Recidivism was more frequent and more severe for the TCC group than the MHC group.

Redlich, A. D., Steadman, H.J., Monahan, J., Robbins, P.C., \& Petrila, J. (2006). Patterns of practice in mental health courts: A national survey. Law \& Human Behavior, 30, 347362. Nearly half of adult mental health courts (MHCs; $N=90$ ) primarily served defendants with misdemeanors. Almost all MHCs monitored participants in the community, mostly through mental health professionals or probation officers. Only 2\% of MHCs incarcerated participants for non-compliance; significant predictors of incarcerating non-compliant participants included more participants with felony charges and more frequent judicial status reviews.

Simpson, A.I.F., Jones, R.M., Evans, C., \& McKenna, B. (2006). Outcome of patients rehabilitated through a New Zealand forensic psychiatry service: A 7.5 year retrospective study. Behavioral Sciences and the Law, 24, 833843. Psychiatric inpatients $(N=105)$, most with psychotic diagnoses (89\%) and violent index offenses, were discharged to a forensic community team (FCT) for follow-up treatment. As of June, 2006, $19 \%$ had been readmitted for further treatment and $42 \%$ had some form of contact with the justice system. However, 42\% lived independently and 52\% were employed. No significant differences were noted between readmitted patients and others.

Taxman, F.S., \& Bouffard, J.A. (2005). Treatment as part of drug court: The impact on graduation rates. Journal of Offender Rehabilitation, 42, 23-50. Logistic regression indicated that drug court completion was positively related to longer program participation, high school education, and being non-white, and it was negatively correlated with prior treatment and participating in government programs among 2,357 participants. Program graduation and current felony charges predicted less likelihood of any rearrest and longer time to rearrest. Number of prior arrests was positively related to any rearrest but negatively related to time to rearrest.

\section{FORENSICEVALUATION}

Boccaccini, M.T., Murrie, D.C., \& Duncan, S.A. (2006). Screening for malingering in a criminal-forensic sample with the Personality Assessment Inventory. Psychological Assessment, 18, 415-423. Data from 154 adult male defendants who were court-referred for pretrial forensic evaluations indicated that the PAI's NIM scale (AUC $=.88$ ) was as effective as the MMPI2 scales of $F$ and $F$ - $K$ for identifying malingerers classified by the Structured Interview of Reported Symptoms (SIRS). Hierarchical logistic regression revealed that the NIM and the $F$ scales uniquely contributed to the identification of malingering.

Farkas, M.R., Rosenfeld, B., Robbins, R., \& van Gorp, W. (2006). Do tests of malingering concur? Concordance

AP-LS NEWS, Winter 2007 
among malingering measures. Behavioral Sciences and the Law, 24, 659-671. Measures of psychopathology and cognitive functioning (MCMI-III, FIT, VIP) obtained from forensic psychologists' reports $(N=66)$ were analyzed for agreement in report conclusions about malingering (honest, indeterminate, malingering). Many of the measures were highly correlated. "Actual” malingering was determined by the MMPI-2 F scale $(>=106 \mathrm{~T})$ and the TOMM $(>=44 T)$. Agreement in classification between tests was high for the malingering group identified by the F scale. Measures of psychopathology were less capable of detecting malingering as measured by the TOMM.

Ficke, S.L., Hart, K.J., \& Deardorff, P.A. (2006). The performance of incarcerated juveniles on the MacArthur Competence Assessment Tool-Criminal Adjudication (MacCAT-CA). The Journal of the American Academy of Psychiatry and the Law, 34, 360-373. Incarcerated youths $(N=247)$, ages 9-18, were completed the MacCAT-CA, WISC-III or WAIS-III (depending on their age), WRAT3, and BPRS-C. Performance on the MacCAT-CA improved with age, with satisfactory understanding not occurring before age 12. Age and IQ were positively related to the Understanding scale of the MacCAT-CA, while high externalizing was negatively related to the Understanding and Reasoning scales. IQ was positively correlated with the Appreciation scale of the MacCAT-CA, while high externalizing was negatively related to the Appreciation scale.

Guy, L.S., Kwartner, P.P., \& Miller, H.A. (2006). Investigating the M-FAST: Psychomet- ric properties and utility to detect diagnostic specific malingering. Behavioral Sciences and the Law, 24, 687702. M-FAST scores from undergraduate students $(n=228)$ feigning a mental disorder (schizophrenia, MDD, bipolar disorder, and PTSD) were compared to scores from clinically diagnosed psychiatric patients $(n=142)$. Overall, feigned M-FAST total scores were significantly higher than clinical total scores, particularly for schizophrenia and bipolar disorder.

Kruh, I.P., Sullivan, L., Ellis, M., Lexcen, F., \& McClellan, J. (2006). Juvenile competence to stand trial: A historical and empirical analysis of a juvenile forensic evaluation service. International Journal of Forensic Mental Health, 5, 109-123. File data from juveniles referred for competency to stand trial evaluations $(N=253)$ revealed that incompetence was correlated with young age, intellectual impairment, psychotic diagnoses, and special education placements.

Kucharski, L.T., Duncan, S., Egan, S.S., \& Falkenbach, D.M. (2006). Psychopathy and malingering of psychiatric disorder in criminal defendants. Behavioral Sciences and the Law, 24, 633-644. Male criminal defendants $(N=188)$ were classified into levels of psychopathy (high: 30.1\%, moderate: $35.1 \%$, low: $34.6 \%$ ) based on their PCL-R total score. Defendants in the high psychopathy group scored higher on most malingering measures than those in the low group. PCL-R factors significantly predicted malingering (75.4\% correct; affective factor only). However, sensitivity and specificity were poor, and the PCL-R did not add predictive power to existing measures for identifying malingering.

Kucharski, L.T., Falkenbach, D.M., Egan, S.S., \& Duncan, S. (2006). Antisocial personality disorder and the malingering of psychiatric disorder: A study of criminal defendants. International Journal of Forensic Mental Health, 5, 195204. Criminal defendants undergoing a court-ordered evaluation were grouped based on the presence of Antisocial Personality Disorder (APD), the presence of another personality disorder, and those without a personality disorder. The APD group had elevated scores in the SIRS, PAI (NIM), and MMPI-2 (F, Fp, and F-K) compared to the other groups of defendants.

Marshall, M.B., \& Bagby, R.M. (2006). The incremental validity and clinical utility of the MMPI-2 Infrequency Posttraumatic Stress Disorder Scale. Assessment, 13, 417429. Multivariate analyses indicated that undergraduates $(n=77)$ instructed to feign PTSD while completing the MMPI-2 scored significantly higher on the clinical, RC, content, and validity scales compared to when they answered the MMPI-2 honestly and to a group of PTSD patients $(n=199)$. Fptsd was as effective as F (both $\mathrm{AUCs}=.80$ ) in distinguishing between feigned and actual PTSD patients, and $\mathrm{F}_{\mathrm{B}}$ was the best discriminator between the two groups (AUC=.86) among the F scales.

Strong, D.R., Glassmire, D.M., Frederick, R.I., \& Greene, R.L. (2006). Evaluating the latent structure of the MMPI-2 F(p) scale in a forensic sample: $A$ taxometric analysis. Psychological Assessment, 18, 250261. Taxometric analyses of MMPI-2 F(p) scores from 289 male pretrial defendants with high F scores (>17) referred for forensic evaluations suggested that the latent distribution underlying $\mathrm{F}(\mathrm{p})$ scores was taxonic. The taxon group had significantly higher MMPI-2 clinical profiles than the complement group, with significantly higher scores on Scales 6, 8, and 9.

Walsh, T., \& Walsh, Z. The evidentiary introduction of Psychopathy Checklist-Revised assessed psychopathy in U.S. courts: Extent and appropriateness. Law \& Human Behavior, 30, 493-507. Among 76 identified cases in which the PCL-R was used to assess the defendant and introduced into evidence from 1991 to 2004, $90 \%$ occurred during or after 2000. Most cases (75\%) involved the assessment of sexual offenders; other contexts included parole hearings, capital punishment trials, civil commitment hearings, transfers of juvenile to adult court, terminations of parental rights, competency to stand trial determinations, and guilt and sentencing hearings.

\section{LAWENFORCEMENT, CONFESSIONS, \& DECEPTION}

Colwell, L.H., Miller, H.A., Miller, R.S., \& Lyons, P.M. (2006). US police officers' knowledge regarding behaviors indicative of deception: Implications for eradicating erroneous beliefs through training. Psychology, Crime \& Law, 12, 489-503. Law enforcement officers in Texas $(N=109)$ completed a survey about knowledge and attitudes about the detection of deception. Younger, less experienced officers reported more use of deception detection and felt training they had received in deception detection was useful. Officers were able to identify research-supPage 13 
ported deceptive actions at approximately chance levels, with poorer performance in identifying nonverbal behaviors associated with deception.

Crossman, A.M. \& Lewis, M. (2006). Adults' ability to detect children's lying. Behavioral Sciences and the Law, 24, 703715 . Adults $(N=64)$ rated videotapes of children either lying $(n=45)$ or telling the truth $(n=13)$ about peeking at a toy. Overall accuracy was less than chance (42\% for liars, 36\% for truth tellers), with a wide range in accuracy across raters (1284\% accuracy range). Professionals who work with children were the most accurate raters, even outperforming participants with children.

Hartwig, M., Granhag, P.A., Strömwall, L.A., \& Kronkvist, O. (2006). Strategic use of evidence during police interviews: When training to detect deception works. Law \& Human Behavior, 30, 603-619. Police interviewers trained to detect deception ( $n=41)$ were more accurate in their judgments of suspects' deception and were more likely to recognize statement-evidence inconsistency as lying than untrained interviewers $(n=41)$. Trained interviewers used different strategies than untrained interviewers, and lying suspects reported significantly higher cognitive demands during interviews with trained interviewers than untrained interviewers.

Sigurdsson, J.F., Gudjonsson, G.H., Einarsson, E., \& Gudjonsson, G. (2006). Differences in personality and mental state between suspects and witnesses immediately after being interviewed by the police. Psychology, Crime \& Law, 12, 619-628. Icelandic citizens (47 suspects, 31 witnesses) completed personality anfaffective measures imme(4) Page 14 diately following a police interview about their involvement in actual cases. More suspects (43\%) reported seeking treatment for mental health/ substance abuse than witnesses (23\%). Suspects and witnesses differed on almost every measure with small to large effect sizes ( $d=.28-.93)$.

Talwar, V., Lee, K., Bala, N., \& Lindsay, R.C.L. (2006). Adults' judgments of children's coached reports. Law and Human Behavior, 30, 561-570. Undergraduate participants $(N=193)$ watched a video of a child, who was either lying or telling the truth, during a competence examination, testimony, and cross-examination and indicated whether they believed the child was lying. Adults were more accurate at detecting truth-tellers (74\%) than liars (26\%) before crossexamination, but overall accuracy after cross-examination was at chance level (50\%).

Vrij, A., Mann, S., \& Fisher, R. P. (2006). An empirical test of the Behaviour Analysis Interview. Law \& Human Behavior, 30, 329-345. The Behaviour Analysis Interview (BAI) rated undergraduates $(N=40)$ who lied about their participation in a research study as more truthful than those who told the truth. Multivariate analyses indicated that liars appeared more truthful according to the BAI than truth-tellers on both the verbal and non-verbal behaviors.

\section{LEGALDECISION-MAKING}

Butler, B. (2006). The role of death qualification in jurors' susceptibility to pretrial publicity. Journal of Applied Social Psychology, 37, 115-123. Adults $(N=200)$ were interviewed about a highly publicized capital case and their attitudes about the death penalty. Compared to non-death qualified participants, death qualified participants were better able to identify details about the case, watched the news more frequently, and were more punitive in their beliefs about the defendant's guilt. However, the death qualified participants were less likely than non-death qualified participants to report that pretrial publicity had an impact on the trial.

Cole, A. P., \& Thomas, E. A. C. (2006). Group differences in fairness perceptions and decision making in voting rights cases. Law \& Human Behavior, 30, 543-560. More mock jurors from a historically black university ( $n=101)$ supported minority voting rights than those from predominantly white institutions ( $n=203)$, and support was higher among all mock jurors when a racial minority was involved in a simulated voting rights case. Perceived evidence strength and perceived unfairness significantly predicted support for minority voting rights ( $\hat{a}=.66$ and .32, respectively), but institution type, minority type, and perceptions of group rights did not.

Connolly, D. A., \& Read, J. D. (2006). Delayed prosecutions of historic child sexual abuse: Analyses of 2064 Canadian criminal complaints. Law \& Human Behavior, 30, 409-434. Content analysis of 1102 court decisions in child sexual abuse cases indicated that more cases were decided by judges than juries, and conviction rates were higher for jury trials. Generally, claims of more intrusive abuse were associated with more abuse incidents, threats made to victims, longer duration of abuse, and alcohol involvement.

Crawford, E. \& Bull, R. (2006). Teenagers' difficulties with key words regarding the criminal court process. Psy- chology, Crime \& Law, 12, 653-667. Irish schoolchildren $(N=111)$ of various ages $(12$, 13 , and 15) from two separate schools were asked to recognize and describe commonly used legal terms (e.g. judge, defendant, cross-examination). Older students tended to recognize more words and were able to recognize more words than younger students. All children had difficulty comprehending some words.

Freeman, N.J. (2006). Socioeconomic status and belief in a just world: Sentencing of criminal defendants. Journal of Applied Social Psychology, 36, 2379-2394. College students $(N=273)$ who varied in their belief in a just world (BJW: high/low) made guilt and punishment ratings based on a vignette about a murder that varied according to the defendant's socioeconomic status (high/low/unknown). High BJW participants rated low SES defendants as more guilty and responsible than low BJW participants. Low SES defendants were seen as more guilty and sentenced more harshly than high SES defendants.

Green, E.G.T., Staerklé, C., \& Sears, D.O. (2006). Symbolic racism and whites' attitudes towards punitive and preventive crime policies. Law \& Human Behavior, 30, 435-454. Symbolic racism among white adults ( $N=849)$ and attributing crime to individual factors significantly predicted support for punitive crime policies. Support for preventive crime policies was best predicted by structural attributions for crime, symbolic racism, and conservatism. Internal symbolic racism was more predictive of punitive policies and external symbolic racism was more predictive of preventive policies, but stepwise regres-

AP-LS NEWS, Winter 2007 
sion indicated unique effects for both in predicting support for the two types of policies.

Koehler, J.J. \& Thompson, W.C. (2006). Mock jurors' reactions to selective presentation of evidence from multipleopportunity searches. Law and Human Behavior, 30, 455468. Undergraduate mock jurors ( $n=301$ ) read a written description of an attempted rape trial. When investigators had investigated a broad range of evidence but presented only two pieces of evidence at trial, the case was judged weaker than if they had investigated a narrow range of evidence and presented two pieces of evidence at trial (Cohen's $d=1.20$ ). Probability of guilt was judged lower in the broad condition than the narrow condition (Cohen's $d=1.18$ ).

Mercado, C.C., Bornstein, B.H., \& Schopp, R.F. (2006). Decision-making about volitional impairment in sexually violent predators. Law and Human Behavior, 30, 587-602. Participants in three groups, legal professionals $(n=43)$, psychologists $(n=40)$, and mock jurors ( $n=76)$, evaluated vignettes depicting four types of volitional impairment in sexually violent predators. The defendant was more likely to be found able to control his conduct if he stated that he could control his behavior than if he stated that he could not $\left(\eta^{2}=.42\right)$. He was rated as less able to control his conduct if he had a history of pedophilia $\left(\eta^{2}=.30\right)$ or if the assault was unplanned $\left(\eta^{2}=.04\right)$.

Miller, M.K. \& Bornstein, B.H. (2006). The use of religion in death penalty sentencing trials. Law and Human Behavior, 30, 675-684. Death qualified ( $n=184)$ mock jurors were asked to make a sentencing decision based upon a written

AP-LS NEWS, Winter 2007 summary of the penalty phase of a capital trial. The type of religious appeal used by the prosecution did not have an influence on verdicts; however, the type of religious appeal used by the defense did have an effect, with a description of the defendant as a “Converted Christian” having a stronger mitigating effect that a Bible-based appeal.

Myers, B., Latter, R., \& Abdolahi-Arena, M.K. (2006). The court of public opinion: Lay perceptions of polygraph testing. Law \& Human Behavior, 30, 509-523. Mock jurors $(N=362)$ who read a summary of a simulated sexual assault trial did not differ in conviction rates or estimated probability of commission by defendant, regardless if they received information about defendant passing or failing a polygraph, or no such information. Those who received polygraph information rated the information as not very influential in their verdicts. Most perceived polygraphs as useful but less trustworthy than other kinds of evidence.

Read, J.D., Connolly, D.A., \& Welsh, A. An archival analysis of actual cases of historic child sexual abuse: A comparison of jury and bench trials. Law \& Human Behavior, 30, 259-285. Juries were 13 times more likely to find defendants in sexual abuse trials guilty than judges $(N=1100)$. Logistic regression results suggested that both judges and jurors were more likely to convict when the offender and victim were related. Additional predictors of conviction included complainant's age and use of threat for juries and length of delay to trial and abuse involving penetration for judges. Juries were less likely to convict when a mental health expert testified for the prosecution, and judges were less likely to convict when such an expert testified for the defense.

Ruva, C., McEvoy, C., \& Bryant, J.B. (2007). Effects of pre-trial and jury deliberation on juror bias and source memory errors. Applied Cognitive Psychology, 21, 4567. Undergraduates ( $N=558)$, half of whom were exposed to pretrial publicity (PTP) and half who were not, watched a shortened version of a real trial and then deliberated individually or in groups. Those exposed to the PTP were more likely to vote guilty and assign longer sentences. There were no significant effects for type of deliberation.

Scott, E.S., Reppucci, N.D., Antonishak, J. \& DeGennaro, J.T. (2006). Public attitudes about the culpability and punishment of young offenders. Behavioral Sciences and the Law, 24, 815-832. An adult community sample $(N=604)$ viewed a short videotape of a robbery committed by a masked male and reviewed a photo that varied by ethnicity (Caucasian/African American), age $(12,15,20)$ and maturity (typical/mature 12 or 15 year-old). Age was the only experimental variable associated with perceptions of maturity, responsibility, and decisions about waiver to adult court. Politically conservative participants were more punitive. In a second study, 185 participants made the same ratings of "tough" photographs without major differences in results.

Sommers, S.R. (2006). On racial diversity and group decision making: Identifying multiple effects of racial composition on jury deliberations. Journal of Personality and Social Psychology, 90, 597612. Adults ( $N=200 ; 29$ mock juries) in a video trial simula- tion with an African American defendant completed one of two voir dire questionnaires (neutral/race-relevant) and deliberated in 6-person groups (all-white/diverse). Pre-deliberation guilt verdicts were related to race, with Caucasians voting guilty more often in allwhite juries but not in diverse groups. Participants who underwent race-relevant voir dire questioning gave fewer guilty verdicts. Diverse juries deliberated longer, in more detail, and with fewer incorrect statements than all-white juries; the level of participation for Caucasian jurors was higher in diverse juries than in all-white juries.

Steblay, N., Hosch, H.M., Culhane, S.E., McWethy, A. (2006). The impact on juror verdicts of judicial instruction to disregard inadmissible evidence: A meta-analysis. Law and Human Behavior, 30, 469-492. Meta-analysis was used to examine the impact of inadmissible evidence (IE) on jurors' verdicts in 48 studies (Total $N=8,474)$. Overall, the presence of IE was associated with a small , but statistically significant increase guilty verdicts despite judges' instructions to disregard the IE ( $r=$ .04 , range of effects $=-.73$ to .47 )

\section{RISKASSESSMENT}

Cunningham, M.D., \& Sorensen, J.R. (2006). Nothing to lose? A comparative examination of prison misconduct rates among life-without-parole and other long-term highsecurity inmates. Criminal Justice and Behavior, 33, 683705. Rates of inmate disciplinary infractions and potentially violent rule infractions were found to be similar for inmates sentenced to life-without-parole $(n=1,897)$ and inmates sentenced to long-term sentences

Page 15 
of 10 to 30 or more years $(n=7,147)$.

Doyle, M. \& Dolan, M. (2006). Evaluating the validity of anger regulation problems, interpersonal style, and disturbed mental state for predicting inpatient violence. $\mathrm{Be}$ havioral Sciences and the Law, 24, 783-798. In a sample of forensic psychiatric inpatients ( $N=94$; $91.2 \%$ male), several anger and psychiatric rating measures were predictive of violent acts or threats. A dominant, coercive, and hostile interpersonal style was associated with an increased likelihood of violent behavior, while a compliant style was associated with a decreased likelihood of violent behavior.

Gavazzi, S.M., Yarcheck, C.M., \& Chesney-Lind, M. (2006). Global risk indicators and the role of gender in a juvenile detection sample. Criminal Justice and Behavior, 33, 597612 . Youth assigned to a detention facility $(N=305)$ were assessed using the Global Risk Assessment Device (GRAD). Females $(n=145)$ were more likely to score higher on the traumatic event, mental health issues, family/parenting issues, and health risk domains of the GRAD. Males $(n=130)$ were more likely to be charged with property and person-related offenses and to score higher on the prior offenses domain of the GRAD.

Hanley, D. (2006). Appropriate services: Examining the case classification principle. Journal of Offender Rehabilitation, 42, 1-22. Three logistic models based on data from offenders $(N=1100)$ in intensive supervision programs (ISPs) indicated that higher risk, based on age and criminal history, and lower age of assignment to ISPs were related to higher rates of recidi- vism. More direct contact (supervision and treatment) was associated with lower rates of recidivism, while appropriateness of services (defined as matching risk and service levels) predicted lower rearrest rates but higher technical violation rates.

Kwartner, P.P., Lyons, P.M., \& Boccaccini, M.T. (2006). Judges' risk communication preferences in risk for future violence cases. International Journal of Forensic Mental Health, 5, 185-194. Judges from Florida, Georgia, and Texas $(n=116)$ rated the probative value of risk communication messages that varied with respect format (categorical, frequency, and probabilistic risk) and risk level (high vs. low). Judges gave higher probative-value ratings to categorical risk messages than numerical-format messages, and expressed a preference for messages that combined categorical and numerical information.

Lewis, C.F., Fields, C., \& Rainey, E. (2006). A study of geriatric forensic evaluees: Who are the violent elderly? Journal of the American Academy of Psychiatry and the Law, 34, 324-332. Records from elderly forensic evaluees' charts $(N=99)$ were reviewed for information about violent behavior/arrests. $60.6 \%$ of the sample had been arrested for a violent crime. Age (ranging from 60-82) was not a significant predictor of violence. $80.8 \%$ of those arrested for a violent crime had been convicted of at least 1 other violent crime.

Luchins, D.J., Cooper, A.E., Hanrahan, P., \& Heyrman, M.K. (2006). Lawyers' attitudes toward involuntary treatment. Journal of the American Academy of Psychiatry and the Law, 34, 492500 . Lawyers $(N=89)$ completed a survey about their at- titudes towards civil commitment and responsibility for the onset and recurrence of mental illness. This survey included 3 vignettes: one with someone with a mental illness and very low risk of harm to self or others, one with high risk of harm to self, and one of high risk of harm to their mother. Respondents were more likely to recommend commitment in both of the high risk vignettes. They also considered $15 \%$ of those with mental illness personally responsible for onset of their mental illness and 31\% responsible for reoccurrence.

Miller, H.A. (2006). Adynamic assessment of offender risk, needs, and strengths in a sample of pre-release general offenders. Behavioral Sciences and the Law, 24, 767782. Concurrent and predictive validity of the Inventory of Offender Risk, Needs, and Strengths (IORNS) as a measure of static, dynamic, and protective factors was evaluated in a sample of male offenders $(N=162)$. Scores from the IORNS were moderately to strongly related (-.28-.63) to existing measures of offender risk and pathology (PAI, CESD, STAI, and LSRP). Rule violators scored higher on Overall Risk and Dynamic Needs indices of the IORNS, and lower on Protective Strengths than offenders who did not break house rules or reoffend during the 15-month follow-up period.

Ogloff, J.R.P. \& Daffern, M. (2006). The dynamic appraisal of situational aggression: An instrument to assess risk for imminent aggression in psychiatric inpatients. Behavioral Sciences and the Law, $24,799-813$. Nurses rated aggression risk for 100 (78 male, 22 female) psychiatric inpatients before and after completing training in the use of risk assessment instruments. Nurse predictions were more accurate after the training. Items related to aggression were compiled to form a brief risk assessment instrument (Dynamic Appraisal of Situational Aggression).

Phillipse, M.W.G., Koeter, M.W.J., van der Staak, C.P.F., \& van den Brink, W. Static and dynamic patient characteristics as predictors of criminal recidivism: A prospective study in a Dutch Forensic Psychiatric sample. Law \& Human Behavior, 30, 309-327. Cox regression analysis of static risk factors in forensic psychiatric inpatients $(N=132)$ suggested that absence without leave during treatment, comorbidity of personality and substance use disorders at admission, and diagnosis of a Cluster B personality disorder at admission were associated with an increased risk of violent recidivism, while psychosis at admission was associated with lowered risk.

Quinsey, V.L., Jones, G.B., Book, A.S., \& Barr, K.N. (2006). The dynamic prediction of antisocial behavior among forensic psychiatric patients: A prospective field study. Journal of Interpersonal Violence, 21, 1539-1565. Staff ratings using the Proximal Risk Factor Scale and the Problem Identification Checklist were completed by mental health professionals and nurses for forensic psychiatric patients $(N=595)$ over a 33 month period. Increases in monthly staff ratings of dynamic risk were predictive of antisocial and violent behaviors.

Schmidt, F., McKinnon, L., Chattha, H.K., \& Brownlee, K. (2006). Concurrent and predictive validity of the Psychopathy Checklist: Youth Version across gender and ethnicity. Psychological Assessment, 18, 393-401. PCL-YV 
total scores were significantly correlated with parent- and youth-reported externalizing and internalizing behaviors in a community sample of adjudicated youths $(N=130)$, with some gender and ethnicity differences. Ethnicity, PCL-YV total scores, and their interaction effect were significant predictors for violent recidivism(VR). Stepwise logistic regression revealed that the addition of ethnicity, gender, and PCL-YV total scores to externalizing behaviors and past criminal offenses significantly improved the prediction of VR.

Sung, H.E., \& Belenko, S. (2005). Failure after success: Correlates of recidivism among individuals who successfully completed coerced drug treatment. Journal of Offender Rehabilitation, 42, 75-97. Logistic regression models of data from 156 successful completers of mandated, long-term residential drug treatment program correctly identified $55-61 \%$ of post-treatment recidivists. Criminal history and length of stay were not predictive of recidivism, and drug use history only predicted short-term recidivism. Treatment variables associated with an increased likelihood of recidivism included previous interest in treatment, perceiving treatment rules as difficult, and perceiving treatment stay as too long.

\section{SEXOFFENDERS}

Barbaree, H.E., Langton, C.M., \& Peacock, E.J. (2006). Different actuarial risk measures produce different risk rankings for sexual offenders. Sex Abuse, 18, 423-440. Mean differences between percentile ranks on the RRASOR, Static99, VRAG, SORAG, and MnSOST-R were computed. Results indicated that discrepancies between the instruments can be accounted for by AP-LS NEWS, Winter 2007 item content related to antisocial behavior and sexual deviance.

Beech, A. \& Ford, H. (2006). The relationship between risk, deviance, treatment outcome and sexual reconviction in a sample of child sexual abusers completing residential treatment for their offending. Psychology, Crime \& Law, 12, 685-701. Risk (static/dynamic), socio-affective functioning, and attitudes about child abuse were measured (pre and post-treatment) for sexual offenders $(N=51)$ treated at a CBT clinic. Offenders were categorized by the research team according to deviance (high/low) and risk (very high/high/medium/low). Membership in the high risk and deviance categories was related to reconviction at follow-up (2 and 5 years), with no reconviction for those who responded to treatment.

Beech, A.R., Ward, T., \& Fisher, D. (2006). The identification of sexual and violent motivations in men who assault women: implication for treatment. Journal of Interpersonal Violence, 21, 1635-1653. Analyses of qualitative interviews of sex offenders $(N=41)$ were used to identified three groups of rapists: violently motivated, sexually motivated, and sadistically motivated offenders.

Eastman, B. (2006). Variables associated with treatment failure among adolescent sex offenders. Journal of Offender Rehabilitation, 42, 23-40. Discriminant function analysis of demographic, criminal, and treatment information from 138 adolescent males court-mandated to residential sex offender treatment correctly classified $84.3 \%$ of offenders into treatment status groups: entering treatment, completed treatment, and failed to complete treatment. Engaging in cognitive distortions was the most important predictor of treatment status.

Firestone, P., Kingston, D.A., Wexler, A., \& Bradford, J.M. (2006). Long-term follow-up of exhibitionists: Psychological, phallometric, and offense characteristic. Journal of the American Academy of Psychiatry and the Law, 34, 349359. Recidivism rates for 208 exhibitionists evaluated over a 13 year period revealed that $23.6 \%$ were charged with a sexual reoffense, $31.3 \%$ were charged with a violent reoffense, and 38.9\% were charged with a non-violent criminal reoffense. Overall, those who reoffended scored higher on the PCL-R, MAST and Pedophile Index than those who did not reoffend.

Hanson, R.K. (2006). Does the Static-99 predict recidivism among older sexual offenders? Sex Abuse, 18, 343-355. Recidivism data were collected on released sex offenders $(n=3425)$. Older sexual offenders tended to have lower Static-99 scores than younger sex offenders. Sexual recidivism rates for older offenders was lower than would be expected given their Static-99 classification.

Kadambi, M., \& Truscott, D. (2006). Concept mapping professionals' perceptions of reward and motive in providing sex offender treatment. Journal of Offender Rehabilitation, 42, 27-48. Qualitative analyses of data from 82 sex offender treatment providers identified 7 themes of perceived rewards of their work. Based on subsequent ratings from a subset of the sample $(n=30)$, the themes in order of importance were: protection of potential victims, socially meaningful curiosity, enjoyment of counseling, professional benefits, connection to colleagues, offender change and wellness, and offendingspecific change.

Kjellgren, C., Wassberg, A., Carlberg, M., Langstrom, N., \& Svedin, C.G. (2006). Adolescent sexual offenders: a total survey of referrals to social services in Sweden and subgroup characteristics. Sex Abuse, 18, 357-372. Social workers were surveyed regarding offense characteristics of adolescent sex offender referrals ( $n=197)$. Forty-six percent of the sample offended against younger children, as opposed to a peers. Forty-two percent of the sample reported offending with at least one other offender.

Langton, C.M., Barbaree, H.E., Seto, M.C., Peacock, E.J., Harkins, L., \& Hansen, K.T. (2006). Actuarial assessment of risk for reoffense among adult sex offenders: Evaluating the predictive accuracy of the STATIC-2002 and five other instruments. Criminal Justice and Behavior, 34, 37 59. Files from 476 adult male sex offenders were used to score the VRAG, SORAG, RRASOR, STATIC-99, STATIC-2002, and the MnSOST-R. The average amount of follow-up time was 5.9 years. Recidivism was found to be $39 \%$ for any type of reoffence, $29 \%$ for non-violent, non-sexual crimes, 25\% for serious recidivism, and $11 \%$ for sexual recidivism. All measures significantly predicted both sexual and serious recidivism, but there were no differences in the accuracy of instruments that were specifically developed to predict sexual recidivism.

Levenson, J.S., \& Morin, J.W. (2006). Factors predicting selection of sexually violent predators for civil commitment. International Journal of Offender Therapy and ComPage 17 
parative Criminology, 50, 609629. In a sample of adult male sex offenders evaluated for civil commitment $(N=450)$, high scores on the STATIC99 and MnSOST-R, diagnoses of pedophilia and paraphilia NOS, high psychopathy (PCLR score), youth of victim, and non-minority race were the best indicators of commitment.

Middleton, D., Elliott, I.A., Mandeville-Norden, R., \& Beech, A.R. (2006). An investigation into the applicability of the Ward and Siegert Pathways Model of child sexual abuse with Internet offenders. Psychology, Crime \& Law, 12, 589-603. Males $(N=72)$ with internet-related child pornography convictions completed a treatment assessment battery either before or during treatment. Measures were assigned to one of five pathways of sexual offending based on the Pathways Model (Ward \& Siegert, 2002). The most common pathways for offenders in the sample were intimacy deficits (35\%), emotional dysregulation (33\%), or multiple pathways (23\%).

Parks, G.A., \& Bard, D.E. (2006). Risk factors for adolescent sex offender recidivism: Evaluation of predictive factors and comparison of three groups based upon victim type. Sex Abuse, 18, 319342. Adolescent male sex offenders $(N=156)$ were grouped according to their victim (child, peer/adult, mixed) and retrospectively assessed for risk factors using the JSOAPII and the PCL:YV. Mixed offenders scored higher than child and peer/adult offenders on both measures. Recidivism data revealed that $6.4 \%$ of the sample reoffended sexually and $30.1 \%$ reoffended nonsexually.

Reimer, W.L., \& Mathieu, T. (2406). Therapeutic factors in (\) Page 18 group treatment as perceived by sex offenders: A “consumers' report." Journal of Offender Rehabilitation, 42, 5973. Thirty-four incarcerated adult males who completed residential sex offender treatment rated catharsis and selfunderstanding as the most beneficial therapeutic factors of group treatment. Age, number of previous sex offenses, PCL-R total scores, and scores on the MCMI-III antisocial personality scale were not significantly correlated with ratings of therapeutic factors; only education was positively related to catharsis, self-understanding, cohesion and universality.

Reitzel, L.R., \& Carbonell, J.L. (2006). The effectiveness of sexual offender treatment for juveniles as measured by recidivism: Ameta-analysis. Sex Abuse, 18, 401-421. Metaanalysis was used to examine the effectiveness of juvenile sex offender treatment across nine studies. An average followup time of 59 months was reported, and recidivism rates for sexual (12.53\%), nonsexual violent (24.73\%), nonsexual non-violent (28.51\%), and unspecified (20.40\%) juvenile sex offenses were computed ( $n=2986)$. A significant effect of treatment on sexual recidivism was found.

Rice, M.E., Harris, G.T., Lang, C., \& Cormier, C. (2006). Violent sex offenses: How are they best measured from official records? Law \& Human Behavior, 30, 525-541. Among 177 adult male sex offenders, legal records of the referral offense categorized only $71 \%$ of those identified by clinical information (e.g., offender and victim statements, psychosocial histories, phallometric test results) as offenders who committed their referral offense with violent sexual motivation. Legal records misidentified all sexually motivated homicides and approximately one-third of sexually motivated assaults. Estimated sexual recidivism (based on legal records and study's results) was more highly correlated with recorded violent recidivism than recorded sexual recidivism.

Worling, J.R. (2006). Assessing sexual arousal with adolescent males who have offended sexually: Self-report and unobtrusively measured viewing time. Sex Abuse, 18, 383-400. Three approaches for assessing sexual arousal in adolescent males $(N=78)$ were compared. Self-report procedures were able to accurately differentiate offenders who assaulted adults from those who assaulted children, and those who assaulted males as opposed to females. The viewing time approach accurately identified offenders with male child victims. No assessment technique was able to accurately identify offenders who exclusively chose female child victims.

\section{WITNESS ISSUES}

Centofanti, A.T. \& Reece, J. (2006). The cognitive interview and its effect on misleading postevent information. Psychology, Crime \& Law, 12, 669-683. Community members $(N=40)$ were interviewed (cognitive interview $=\mathrm{CI}$, structured interview $=$ SI) after viewing a videotaped robbery and reading a narrative of the video with misleading or neutral target details. More details were recalled by CI participants. SI participants made fewer errors in the misleading group than in the neutral detail group. Participants in the misleading details group recalled more incorrect target items.

Dattilio, F.M., Commons, M.L., Adams, K.M., Gutheil, T.G., \& Sadoff, R.L. (2006). A pilot Rasch scaling of lawyers' per- ceptions of expert bias. Journal of the American Academy of Psychiatry and the Law, 34, 482-491. Forty attorneys completed a questionnaire about expert witnesses, expert bias, and biasing factors. Attorneys reported that experts who work for both sides are less biased, but that they prefer those who usually work for one side.

Deffenbacher, K.A., Bornstein, B.H., \& Penrod, S.D. (2006). Mugshot exposure effects: Retroactive interference, mugshot commitment, source confusion, and unconscious transference. Law \& Human Behavior, 30, 287-307. Separate meta-analyses indicated that mugshot exposure decreased correct identification/ rejection rates $(k=15 ; h=-.15)$ and increased false alarm rates ( $k=25 ; h=.48)$ in subsequent lineups, with stronger effects observed in mugshot commitment studies. A third metaanalysis $(k=19)$ revealed that use of a transference design increased rates of transference error $(h=.34)$. More transference errors were observed in studies with mugshot exposure and with presence of a mugshot (versus bystander) in subsequent line-up.

Douglass, A.B., \& McQuiston-Surrett, D. (2006). Post-identification feedback: Exploring the effects of sequential photo spreads and eyewitness' awareness of the identification task. Applied Cognitive Psychology, 20, 991-1007. Experiment 1, $(N=254)$ undergrads viewed a video and were presented with a target-absent photo spread that was either simultaneous or sequential. $99 \%$ of those in the simultaneous condition and $89 \%$ in the sequential condition made an identification. Post- identification feedback affected those who saw a simultaneous spread, were sus-

AP-LS NEWS, Winter 2007 
picious about having to make an identification, and received positive feedback. Experiment 2 , $(N=320)$ undergrads repeated the design of Experiment 1 with an added manipulation of witnesses' expectations of whether they would have to make an identification. The feedback effect was the same across expectations and lineup type.

Douglass, A.B., \& Steblay, N. (2006). Memory distortion in eyewitnesses: A meta-analysis of the post-identification feedback effect. Applied Cognitive Psychology, 20, 859-869. The influence of post-identification feedback on eyewitnesses was examined using 20 effects from 14 studies (Total $\mathrm{N}=2477$ ). Large Cohen's d effect sizes for confirmatory feedback were found for certainty at time of ID (0.79), good basis to make an ID (0.77), ease of making an ID (0.80), willingness to testify (0.82), and clarity of image in my mind (0.68). Medium effect sizes were found for how good a view (0.50), opportunity to view face (0.55), attention paid (0.46), speed of ID (0.45), my memory for strangers (0.45), trust in eyewitnesses with similar experiences (0.52), and confidence right now (0.53). Small effect sizes were found for how far away (0.12) and how long in view (0.29).

Geraerts, E., Jelicic, M., \& Merckelbach, H. (2006). Symptom overreporting and recovered memories of childhood sexual abuse. Law \& Human Behavior, 30, 621-630. Participants with recovered $(n=66)$ and continuous ( $n=119)$ childhood sexual abuse memories reported significantly higher severity of childhood trauma and scored significantly higher on a symptom-overreporting measure than participants without an abuse history

AP-LS NEWS, Winter 2007 $(n=83)$. Separate samples of participants with recovered $(n=45)$ and continuous $(n=45)$ memories did not differ in their reports of the severity of childhood trauma, performance on a facial expression task, or current level of trauma-related distress.

Gilbert, J.A.E., \& Fisher, R.P. (2006). The effects of varied retrieval cues on reminiscence in eyewitness memory. Applied Cognitive Psychology, 20, 723-739. Undergraduates $(N=168)$ were shown a video of a robbery and then asked to provide testimony under 1 of 5 conditions (free recall, chronological, reverse chronological, police's perspective, or robber's perspective) and then to provide testimony again, 2 days later, with random placement in one of the same 5 testimony conditions. Changing conditions between trials significantly increased reported recall of new information in the second testimony.

Goodman, G.S., Myers, J.E.B., Qin, J., Quas, J.A., Castelli, P., Redlich, A.D., et al. (2006).

Hearsay versus children's testimony: Effects of truthful and deceptive statements on jurors' decisions. Law \& Human Behavior, 30, 363-401. Jurors' $(N=370)$ perceptions of children's testimony accuracy was generally unrelated to actual accuracy in 36 mock trials involving a child victim. Path analysis indicated that live testimony from a witness increased perceptions of his/her credibility, live testimony from child increased sympathy toward him/her, and female jurors perceived testimony as more truthful. These factors, in turn, positively predicted confidence in the defendant's guilt.

Leippe, M.R., Eisenstadt, D., Rauch, S.M., \& Stambush, M.A. (2006). Effects of socialcomparative memory feedback on eyewitnesses' identification confidence, suggestibility, and retrospective memory reports. Basic and Applied Social Psychology, 28, 201220. Undergraduates $(N=169)$ viewed a videotaped robbery and reported robbery details to a "listener." Before being interviewed (regular or misleading questions), they were told that a co-witness' report agreed/disagreed with theirs, was more/less accurate, or were told nothing. With feedback, misleading questions led to suggestibility and differences in line-up identification. Later, 127 undergraduates were given more specific feedback in a similar task. Positive feedback was related to line-up accuracy (more than no feedback).

Odinot, G., \& Wolters, G. (2006). Repeated recall, retention interval and the accuracy-confidence relation in eyewitness memory. Applied Cognitive Psychology, 20, 973-985. Undergraduates $(N=67)$ were assigned to three conditions (three recall sessions 1,3 , and 5 after video presentation; two recall sessions, 3 and 5 weeks after presentation; and one recall session, 5 weeks after presentation). Longer intervals before the first recall session were associated with poorer accuracy and less confidence from witnesses. The number of recall sessions had no effect on accuracy or confidence.

Paterson, H.M., \& Kemp, R.I. (2006). Comparing methods of encountering post-event information: The power of cowitness suggestion. Applied Cognitive Psychology, 20, 1083-1099. Undergraduates ( $N$ $=105$ ) were shown a video of a crime, randomly assigned to a true or false post-event information condition (leading questions, media report, indirect co-witness information, co-witness discussion, or no post event information), and then tested on their memory for the crime 1 week later. Significant effects on accuracy of information recall were found for both true (improved accuracy) and false (lower accuracy) co-witness discussion as compared to no post-event information.

Pozzulo, J.D., Lemieux, J.M.T., Wells, E., \& Mccuaig, H.J. (2006). The influence of eyewitness identification decisions and age of witness on jurors' verdicts and perceptions of reliability. Psychology, Crime \& Law, 12, 641-652. 180 mock jurors were asked to read testimony from a witness that varied in age (9 vs. 42) and the person who he/she identified in a lineup (positive identification, foil, no ID). Guilty verdicts were influenced by identification type (positive ID $=$ more guilty verdicts than no ID), but not witness age. Witnesses who made positive IDs were viewed as more reliable than others. Adults were rated as more credible than children.

Robinson, J. \& McGuire, J. (2006). Suggestibility and children with mild learning disabilities: The use of the cognitive interview. Psychology, Crime \& Law, 12, 537-556. Children with learning disabilities $(n=20)$ were compared to children with average achievement $(n=20)$ on a measure of suggestibility. Children with LD recalled fewer correct details about the measure than the average achievement children. In a second study, 38 children with LD were interviewed (19 using cognitive interview [CI], 19 using structured interview [SI]), about a video clip involving stealing. CI children recalled more correct details than SI children, but children in both groups provided a similar number of incorrect answers and fabrications. 


\section{Nominations, Awards}

\section{Research Briefs Continued from p. 19}

Ross, D.F., Marsil, D.F., Benton, T.R., Hoffman, R., Warren, A. R., Lindsay, R.C.L., et al. (2006). Children's susceptibility to misidentifying a familiar bystander from a lineup: When younger is better. Law \& Human Behavior, 30, 249-257. Among 5-12 year olds $(n=592)$ who viewed a video of a simulated theft with or without bystander and a subsequent lineup of bystander and foils, only 11-12 year olds were susceptible to the bystander effect. The effect was eliminated when they were informed that the bystander and thief were different individuals prior to seeing the same lineup or when they viewed a lineup with both bystander and thief. A separate sample of children $(n=187)$ who viewed the video without a bystander and lineup with a thief present indicated 11-12 year olds were more likely than younger children to correctly identify the theft.

Theodore, A.D., \& Runyan, D.K. (2006). A survey of pediatricians' attitudes and experiences with court in cases of child maltreatment. Child Abuse \& Neglect, 30, 1353-1363. An anonymous survey was completed by $(N=270)$ pediatricians assessing their attitudes and experiences with court cases involving child maltreatment. 96\% reported having made at least one report of suspected abuse or neglect and $10 \%$ reported at least one instance of suspecting abuse/neglect but not reporting it. Those who reported having negative court experiences were less likely than others to report suspected abuse, and more likely to report feeling that court obligations interrupted their schedules and that they were not adequately compensated for their time in court.

Thoresen, C., Lonnum, K., Melinder, A., Stridbeck, U., \& Magnussen, S. (2006). Theory and practice in interviewing young children: A study of Norwegian police interviews. Psychology, Crime \& Law, 12, 629-640. 41 child sexual abuse interviewers were trained in child interviewing techniques (cued recall, openended questions). Videotaped interviews from before, during, and after their training revealed some improvements from training. Use of non-optimal questions (e.g. yes/no) decreased as interviewers incorporated training techniques into interviews. Child interviewing techniques were used most often in the beginning of the interview and more often with younger children.

\section{Congratulations to AP-LS Fellows!}

Congratulations to the recently-elected fellows for AP-LS/Division 41. We elected one individual (Barry Ruback) who was already an APA fellow, and three individuals (Mark Cunningham, Alan Goldstein, and Rich Redding) who are APA fellows for the first time. In addition, we elected Brian Cutler to "Distinguished Member" status. The Cunningham, Goldstein, and Redding nominations needed confirmation by a vote of APA Council, which they received at the New Orleans convention.

\section{and Announcements}

\section{Saleem Shah Award Winner:}

\section{Candice Odgers}

AAFP and APLS wish to congratulation DR. CANDICE ODGERS who is the 2007 winner of the Saleem Shah Early Career Achievement Award. Dr. Odgers is a graduate of the University of Virginia and is currently a Postdoctoral Research Fellow in the Social, Genetic, and Developmental Psychiatry Centre (MRC) at King's College Institute of Psychiatry in London.

Join us in congratulating Dr. Odgers!

\section{Outstanding Teaching \& Mentoring Award}

The Teaching, Training, and Careers Committee of the American Psychology-Law Society is proud to announce that Professor $\mathbf{N}$. Dickon Reppucci of the University of Virginia has been selected as the recipient of the 2007 Award for Outstanding Teaching and Mentoring in the Field of Psychology and Law.

This competitive award is given to a scholar in the field of psychology and law who has made substantial contributions in terms of student teaching and mentoring, teaching-related service and scholarship, development of new curricula, administration of training programs, etc. Professor Reppucci's record is outstanding in all of these ways and more. We congratulate him on this grand achievement.

Past winners of this prestigious award include Professors Gail S. Goodman, Margaret Bull Kovera, Bette Bottoms, and James Ogloff.

\section{APLS BOOK AWARD}

The APLS Book Award Committee is pleased to announce the winners of the award for the outstanding book in Law and Psychology for 2005-2006:

\section{WILLIAM E. FOOTE, Ph.D., ABPP and JANE GOODMAN- DELAHUNTY, J.D., Ph.D., MAPS}

For their 2005 book, EVALUATING SEXUAL HARASSMENT: PSYCHOLOGICAL, SOCIAL,ANDLEGALCONSIDERATIONS IN FORENSIC EXAMINATIONS, published by the American Psychological Association. By providing psychologists with essential information to conduct an evidence-based forensic practice involving sexual harassment cases, the book makes an outstanding contribution to the field of psychology and law.

We congratulate Drs. Foote and Goodman-Delahunty for their achievement! 


\section{Nominations, Awards, Perry to Receive Presidential Citation}

Joel Dvoskin, President of AP-LS, has announced that a Presidential citation will be awarded at the APA Convention to Dr. Bruce Duncan Perry. In selecting Dr. Perry for this award, Dvoskin cited the importance of understanding trauma and its effects upon the human brain in a variety of psycholegal contexts, including child custody evaluation, child protection and advocacy, delinquency, disability law, and parental rights. "Public policy regarding children is often based upon mindless political rhetoric," said Dvoskin. "Bruce Perry has offered policy-makers solid scientific data upon which to base decisions. Miraculously, they are starting to listen.” Dr. Dvoskin also noted the importance of understanding childhood trauma and its long-lasting effects in fashioning an adult criminal justice system. "Appropriate treatment requires accurate diagnosis, and for too long, the criminal justice system has ignored the effects of trauma upon the developing brain. While explanation is not excuse, it is only by understanding how someone became a criminal that we can hope to put the word 'correct' back into corrections."

Dr. Bruce Perry is the Senior Fellow of the ChildTrauma Academy, a not-for-profit organization which promotes innovations in service, research, and education concerning child maltreatment and childhood trauma (www.ChildTrauma.org). Dr. Perry is the author of over 300 journal articles, book chapters, and scientific proceedings and is the recipient of numerous professional awards and honors, including the T. Berry Brazelton Infant Mental Health Advocacy Award, the Award for Leadership in Public Child Welfare, and the Alberta Centennial Medal. Over the last 20 years, Dr. Perry has been an active teacher, clinician, and researcher in children's mental health and the neurosciences holding a variety of academic positions. Dr. Perry has conducted both basic neuroscience and clinical research. His neuroscience research has examined the effects of prenatal drug exposure on brain development, the neurobiology of human neuropsychiatric disorders, the neurophysiology of traumatic life events, and basic mechanisms related to the development of neurotransmitter receptors in the brain. His clinical research and practice have focused on high-risk children - examining longterm cognitive, behavioral, emotional, social, and physiological effects of neglect and trauma in children, adolescents and adults. This work has been instrumental in describing how childhood experiences, including neglect and traumatic stress, change the biology of the brain - and, thereby, the health of the child. A focus of his clinical research over the last 10 years has been the integration of concepts of developmental neuroscience and child development into clinical practices. This work has resulted in the development of innovative clinical practices and programs working with maltreated and traumatized children. His experience as a clinician and a researcher with traumatized children has led many community and governmental agencies to consult with Dr. Perry following high-profile incidents involving traumatized children. These include the Branch Davidian siege, the Oklahoma City bombing, the Columbine school shootings, the September 11th terrorist attacks, and the Katrina and Rita hurricanes.

Throughout the years Dr. Perry has been especially interested in using education as a major advocacy tool for high-risk children. A prominent area of focus has been translating emerging concepts

\section{and Announcements}

in developmental neurobiology into practical and useful knowledge for other disciplines. This work has taken many forms including directly teaching and speaking with legislators, judges, state and county officials. Dr. Perry has taught key advocacy-related issues for judges and court personnel through training sponsored by the California, Rhode Island, Colorado, Texas, Ohio, and Oregon Supreme Courts. Dr. Perry has presented on childhood trauma, brain development, impact of violence on the developing child, and a variety of related areas to dozens of legislative bodies and policy-making groups (including the California Assembly, the Oregon House, the National Governor's Association, the National Association of County Officials, committees in the United States Senate and House, the National Mayor's Association, and legislative sub-committees in a dozen states, provinces and abroad in New Zealand and Australia). Dr. Perry was a founding member of the CIVITAS Initiative which developed several interdisciplinary professional training programs (e.g., Child Law at Loyola Law School in Chicago and Social Work at the University of Michigan) which focused on high-risk children. He has presented about child maltreatment, children's mental health, neurodevelopment, and youth violence in a variety of venues including policy-making bodies such as the White House Summit on Violence, the California Assembly, and U.S. House Committee on Education.

\section{Dr. Perry will present an invited address as part of Division 41's program at APA in San Francisco.}

\section{Call for Nominations \\ Master Lecturers \& Distinguished Scientist Lecturers}

The American Psychological Association's (APA) Board of Scientific Affairs (BSA) is soliciting nominations for speakers for the 2008 Master Lecture Program and the 2008 Distinguished Scientist Lecture Program. These annual programs spotlight experts in psychological science and are sponsored by the APA's Science Directorate.

Selected speakers receive an honorarium of $\$ 1,000$ and reimbursement for travel expenses, up to $\$ 1,000$. All nominees should be excellent public speakers. BSA will review all nominations at its 2007 spring meeting and begin to contact potential speakers for these programs. Nominations may be for either the Distinguished Lecture Program or the Master Lecture Program (or both).

The Master Lecture Program, developed by BSA, supports up to five (5) psychological scientists to speak at the APA Annual Convention. A list of previously selected speakers can be found on-line at http://www.apa.org/ science/masterlecturers.html. BSA has organized the lectures into ten core areas that reflect the field. Each year, five of these areas are addressed by Master Lecturers. Speakers for the 2008 Convention, to be held in Boston, MA, August 14-17, 2008, will be chosen to have expertise in each of the following areas: developmental psychology, learning, behavior and action, methodology, psychopathology, social and cultural psychology

The Distinguished Scientist Lecture Program, developed by BSA, supports up to three (3) psychological scientists to speak at Regional Psychological Association meetings to be held in 2008. Speakers must be actively engaged in research, with expertise in any area. A list of previously selected speakers and their topics can be found on-line at http://www.apa.org/science/distsci-lecturer.html.

Please send in the name of your nominee(s) by e-mail or fax to Suzanne Wandersman, APA Science Directorate, 750 First Street, N.E., Washington, DC. 20002-4242 (e-mail: swandersman@apa.org; fax 202-336-5953). Nominations must be received by February 20, 2007.

Page 21 


\section{Division News and Information}

\section{APLS Book Series}

The APLS book series is published by Oxford University Press. The series publishes scholarly work that advances the field of psychology and law by contributing to its theoretical and empirical knowledge base. The latest book, by Roger Levesque, is in press and should be available in Spring, 2007.

The editor is interested in proposals for new books. Inquiries and proposals from potential authors should be sent to Dr. Ronald Roesch, Series Editor (E-mail: roesch@sfu.ca or phone: 604-2913370).

The following books are available for purchase online from Oxford University Press (note that APLS members receive a 25\% discount, as shown on the website): http://www.us.oup.com/us/ collections/apls/?view=usa

Haney, C. (2005). Death by design: Capital punishment as a social psychological system.

Koch, W. J., Douglas, K. S., Nicholls, T. L., \& O’Neill, M. (2005). Psychological injuries: Forensic assessment, treatment and law.

Posey, A. J., \& Wrightsman, L. S. (2005). Trial consulting.

Stefan, S. (2006). Emergency department treatment of the psychiatric patient: Policy issues and legal requirements.

Wrightsman, L. S. (2006). The psychology of the Supreme Court.

Slobogin, C. (2006). Proving the unprovable: The role of law, science, and speculation in adjudicating culpability and dangerousness.

Levesque, R. J. R. (in press). Adolescents, media and the law: What developmental science reveals and free speech requires.

\section{Upcoming American Academy of Forensic Psychology CE Workshops}

\footnotetext{
Montreal, 3/21/07-3/25/07

- Ethical Issues in Forensic Practice, Alan Goldstein, Wednesday.

- Forensic Mental Health Assessment: Principles \& Cases, Kirk Heilbrun, Thursday.

- Children’s Memory: Interviewing Children to Preserve Accurate Testimony, Jodi Quas, Thursday.

- Psychological Independent Medical Examinations: Clinical, Ethical \& Practical Issues, Lisa Piechowski, Friday.

- Risk assessment and risk management in probation and parole settings, Jennifer Skeem, Friday.

- Children, Divorce, and Custody: New Research and New Roles for Psychologists, Robert Emery Children, Saturday.

- Development Pathways to Severe Antisocial \& Aggressive Behavior, Paul Frick, Sat

- Joel Dvoskin Treatment of Offenders with Co-Occurring Disorders: Risk Assessment and Treatment Planning, Sunday.

- Preparing for Board Certification in Forensic Psychology -ABPP, Bill Warnken, Sunday.
}

\section{AAFP Policy for Funding Post-Doctoral Candidates}

The American Academy of Forensic Psychology has developed a new policy to subsidize the forensic diplomate application process for individuals who have completed an approved post-doctoral externship within the past two years.

Procedure:

1. The candidate submits the Initial Application (for the diplomate in forensic psychology (for information, see www.abfp.com). Once approved to go forward, the candidate notifies the President of the American Academy of Forensic Psychology (www.aafp.ws) of the wish to be considered for the subsidization.

2. The President of AAFP will request verification that the candidate has been approved to go forward with the diplomate certification process, and will then submit a voucher to reimburse candidate for the Initial Application fee.

3. As the candidate completes each step of the process, including the written examination, the practice sample review, and the oral examination, the fee for each step will be reimbursed in the same manner.

4. This subsidization will be considered for the candidate's initial effort through this process; should it be necessary to repeat a step, the subsidization will not be available.

\section{American Academy of Forensic Psychology Workshop Schedule: 2005-2006}

The American Academy of Forensic Psychology, the membership of ABPP board certified forensic psychologists, presents an ongoing series of workshops and training seminars led by leaders in the field of forensic psychology. Workshops focus on contemporary psycho-legal issues relevant to forensic, child, clinical and neuropsychologists and are designed for those interested in pursuing psycho-legal topics in depth.

The schedule for 2006-2007 can be found at www.abfp.com, along with a listing of the specific topics covered in each workshops. More information also appears in Conference and Workshop planner on page 44 and detailed information about upcoming workshops appears to the left.

The American Academy of Forensic Psychology is approved by the American Psychological Association to offer continuing education for psychologists. AAFP maintains responsibility for its programs. 


\title{
Division News and Information
}

\author{
APLS 2008 Annual Conference \\ Jacksonville, Florida - March 5-8
}

The 2008 annual conference will be held at the Hyatt Regency in downtown Jacksonville, Florida. Pre-conference workshops will take place on Wednesday, March $5^{\text {th }}$, with the regular conference programming beginning midday Thursday, March $6^{\text {th }}$ and ending late in the evening on Saturday, March $7^{\text {th }}$.

Visit the conference website by following the "Conference" link on the AP-LS homepage at www.ap-ls.org or directly via http://www.apls.org/conferences/apls/apls2008.html

Proposals will be accepted through the above website from July $1^{\text {st }}, 2007$ through September $21^{\text {st }}, 2007$.

If you have any questions, suggestions, or comments about the conference, please feel free to contact one of the conference co-chairs listed below.

Kevin O’Neil, J.D., Ph.D

Dept. of Psychology

Florida International Univ.

Office Phone: 305-919-5249

Email: oneilk@fiu.edu

David DeMatteo, J.D., Ph.D

Dept. of Psychology

Drexel University

Office Phone: 215-762-8342

Email: dsd25@drexel.edu
Eve Brank, J.D., Ph.D

Dept. of Crim., Law and Society

University of Florida

Office phone: 352-392-1025 x 208

Email: ebrank@ufl.edu

\section{We'll see you in Jacksonville!}

\section{Psychology, Public Policy \& Law: Editorial Statement}

Psychology, Public Policy, and Law focuses on the links between psychology as a science and public policy and law. It publishes articles of modest length that (a) critically evaluate the contributions and potential contributions of psychology and relevant information derived from related behavioral and social sciences to public policy and legal issues; (b) assess the desirability of different public policy and legal alternatives in light of the scientific knowledge base in psychology; and (c) examine public policy and legal issues relating to the science and practice of psychology and related disciplines. Although some of these issues may be addressed in articles currently being submitted to traditional law reviews, this publication uniquely provides peer review, both scientific and legal input, and editorial guidance from psychologists and lawyers. Through publication in a single forum, the journal will also focus the attention of scholarly, public policy, and legal audiences on such work. Original empirical research reports that apply psychological science to questions of policy and/or law are welcome and encouraged. Empirical research must make a significant contribution to public policy and/or the law. Such empirical work is preferably multistudy, multijurisdictional, longitudinal, or in some other way either broad in scope, of major national significance, or both.
Fellowship and Position listings are included in the APLS News at no charge as a service to members and affiliates. All listings should be forwarded, in MS Word, WordPerfect, or ascii format, to Barry Rosenfeld, Ph.D. (rosenfeld@fordham.edu). Deadlines are January 1, May 1, and September 1, with each issue being mailed approximately one month later. Any requests for Fellowship and Position listings should include details regarding which issues of the newsletter the listing should be included (i.e., a onetime listing, for a specified number of issues or period of time, or a listing that should appear on a regular schedule).

\section{Membership in EAPL}

Join the EUROPEAN ASSOCIATION OF PSYCHOLOGY AND LAW and receive a subscription to Psychology, Crime and Law for about $\$ 50$ (45 Euros). Information about EAP can be obtained at the Association website: www.law.kuleuven.ac.be/eapl/. Information about Psychology, Crime and Law can be found at www.tandf.co.uk/journals/titles/1068316x.html. Membership is available to psychologists and attorneys, as well as criminologists, sociologists, psychiatrists, and educational scientists. Information on how to join EAPL is also available through the Association website. In addition to a scholarly journal (Psychology, Crime, and Law), EAPL holds an annual meeting, including a joint conference with APLS every fourth year (most recently in Edinburgh, Scotland in July, 2003). This year's conference will be a joint conference held July 3-8, 2007, in Adelaide, Australia. Further details are available through the Association website. 


\section{Division News and Information}

\section{New Task Force for Div 41 and Div 37}

An exciting new interdivisional Task Force is being formed to address the prevention of child maltreatment. Sponsored by Divisions 37 (Child, Youth, and Family Services) and 41 (American Psychology-Law Society), the Task Force will consider the current state of science on child maltreatment prevention and work to identify and disseminate promising programs and strategies. With this knowledge, the Task Force will be in a position to develop initiatives to reach out to practitioners - across the disciplines of law and psychology, as well as others - who work with parents, children, and families. An initial planning group met at the APA Annual Meeting in New Orleans to discuss the potential structure and objectives of the Task Force. The overall goal of the Task Force developers, Bette Bottoms, Gail Goodman, and Joel Dvoskin, is for the Task Force to provide a central point of contact for all child abuse prevention activities across APA. With that in mind, the group's initial focus will be on uniting practice and research, which could take many forms (e.g., direct service, program development, meetings, publications for "front line" professionals). Division 41 members who are interested in participating on the Task Force should contact the Chairs, Sharon Portwood (sgportwo@email.uncc.edu) or Mary Haskett (mary_haskett@ncsu.edu).

\section{EXECUTIVE COMMITTEE AND COMMITTEE CHAIRS}

- President

- Past-President

- President-Elect

- Secretary

- Treasurer

- Member-at-Large

- Member-at-Large

- Member-at-Large

- Council Representative

- Council Representative

- Newsletter Editor

- Publications Editor

- Law \& Human Behavior Editor

- Psychology, Public Policy, \& Law Editor

- Webpage Editor

- Liaison to APA Science Directorate

- Liaison to APA Public Interest Directorate

- Liaison to APA Practice Directorate

- Teaching, Training, and Careers Committee

- Dissertation Awards

- Educational Outreach Committee

- Fellows Committee

- Grants-in-Aid

- Book Award Committee

- Undergraduate Research Award Committee

- Committee on Relations with Other Organizations

- Scientific Review Paper Committee

- Diversity Affairs Committee

- Mentorship Committee

- Division Administrative Secretary

- Conference Advisory Committee

- 2006 APA Program Chairs

- 2008 APLS Conference Chairs

\author{
Joel Dvoskin \\ Gary Wells \\ Margaret Bull Kovera \\ Patricia Zapf \\ Brad McAuliff \\ Kevin Douglas \\ Jennifer Skeem \\ Mary Connell \\ Patty Griffin \\ Beth Wiggins \\ Jennifer Groscup \\ Ron Roesch \\ Brian Cutler \\ Steven Penrod \\ Adam Fried \\ Brian Bornstein \\ Natacha Blain \\ Michele Galietta \\ Allison Redlich \\ Eve Brank \\ Lavita Nadkarni \\ Kirk Heilbrun \\ Beth Bennett \\ Richard Redding \\ Livia Gilstrap \\ Michele Galietta \\ William Thompson \\ Roslyn Caldwell \\ Ryann Haw \\ Lynn Peterson \\ Tonia Nicholls \\ Amy Bradfield \\ Roslyn Caldwell \\ David DeMatteo \\ Kevin O’Neil \\ Eve Brank
}

JoeltheD@aol.com

glwells@iastate.edu

mkovera@jjay.cuny.edu

pzapf@jjay.cuny.edu

bdm8475@csun.edu

douglask@sfu.ca

skeem@uci.edu

mary@maryconnell.com

pgriffin@navpoint.com

bwiggins@fjc.gov

jgroscup@jjay.cuny.edu

roesch@sfu.ca

lhb@email.uncc.edu

spenrod@jjay.cuny.edu

afried@fordham.edu

bbornstein2@unl.edu

natacha.blain@atlahg.org

mgalietta@jjay.cuny.edu

aredlich@prainc.com

ebrank@ufl.edu

lnadkarn@du.edu

kh33@drexel.edu

BBennett@washjeff.edu

redding@law.villanova.edu

lgilstrap@uccs.edu

mgalietta@jjay.cuny.edu

wcthomps@uci.edu

rcaldwell@jjay.cuny.edu

ryannh@bigbend.edu

div41apa@comcast.net

tnichola@sfu.ca

abradfie@bates.edu

rcaldwell@jjay.cuny.edu

dsd25@drexel.edu

oneilk@fiu.edu

ebrank@ufl.edu 


\section{Division News and Information \\ Forensic Specialty Council}

What is the Forensic Specialty Council? Each Specialty recognized by APA (through CRSPPP - the Committee for Recognition of Specialties and Proficiencies in Professional Psychology) or by ABPP is represented on the Council of Specialties in Professional Psychology (COS). The representative to COS is the chair of the Specialty's Council (also known as a "synarchy"), which is composed of representatives of the major stakeholder organizations which comprise the Specialty. In the case of Forensic Psychology, the constituent organizations are AP-LS and ABFP (American Board of Forensic Psychology). I have been appointed, by the Presidents of the two organizations, as Chair of the Forensic Specialty Council (my second 3-year term will expire at the end of 2009). The other members of the Council are:

Richart (Rick) DeMier

John Edens

Antoinette Kavanaugh

Among the most important functions of the Specialty Council are: 1. Responsibility for coordinating the documentation to submit a request for renewal of recognition of our Specialty by CRSPPP (renewal due in 2008)

2. Establishing and updating Education and Training Guidelines for the Specialty

The Council's main focus at present is on the development of the Education and Training Guidelines. These guidelines will cover only "Forensic Psychology" as defined in our CRSPPP petition the idea being to provide guidelines for consistent training of forensic psychology practitioners. These guidelines would not apply to those in "Legal Psychology" or ay researchers/academics who may be called upon to provide testimony or other "non-

\section{Fellow Status in the}

\section{American Psychologial Association}

Becoming a Fellow recognizes outstanding contributions to psychology and is an honor valued by many members. Fellow nominations are made by a Division to which the Member belongs. The minimum standards for Fellow Statusare:

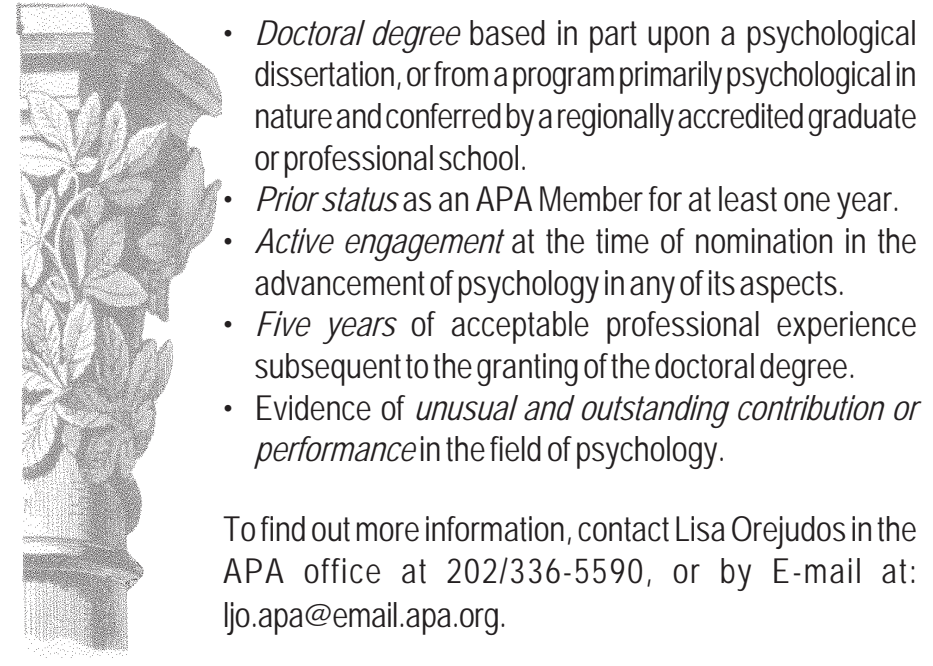

clinical” service. The guidelines will not be retroactive, will have to allow for "grandparenting", and will also have to have a future implementation date (that is, it will apply only to those who will begin training after acceptance of the guidelines).

Some of the major benefits from having E\&T guidelines are: 1) it will allow for accreditation of Postdoctoral Forensic Psychology programs; 2) it should lead to consistency and improved quality of training; and 3) it will likely encourage graduate programs to develop "emphases" or "concentrations" in Forensic Psychology, including courses in this area.

In developing guidelines for Postdoctoral training in Forensic Psychology, we have to date adopted the following principles:

1. Specialization in Forensic Psychology will require broad-based training at the Graduate level, followed by specialized training at the Postdoctoral level (formal Residency or Fellowships). Again, these will be future requirements, putting Forensic Psychology on the same footing as other Specialties. Thus, specialization cannot be obtained solely at the Graduate level.

2. Education at the Graduate level must be from an APA or CPA accredited Doctoral Program. (At present, APA only accredits Graduate Programs in Clinical, Counseling, and School Psychology.) This will ensure that Forensic Psychologists have first achieved competency as general practitioners ("clinicians").

3. Postdoctoral Programs should be designed to allow and encourage their graduates to qualify for Board Certification in Forensic Psychology by ABPP. This is in keeping with the movement, throughout Psychology, to encourage ABPP certification for all Specialists.

4. In keeping with the above, the ideal will be for the Director of a Forensic Psychology Postdoctoral Fellowship (Residency) to be an ABPP in Forensic Psychology. However, at a minimum, there must be at least one faculty member involved in the postdoctoral training program who is an ABPP in Forensic.

5. The Council will be working on fleshing out the details of the E\&T Guidelines, started with the base provided by our 2001 CRSPPP petition. At this point, we are welcoming and soliciting input regarding recommendations for the Guidelines at all levels of training (Graduate, Internship, and Postdoctoral). If you would like to provide input, please email to ira.packer@umassmed.edu and I will disseminate to the other council members. If it turns out that there is a lot of interest, I will try to develop a listserv.

Submitted by Ira K. Packer, Ph.D. 


\section{SARMAC}

The next meeting of the Society for Applied Research in Memory and Cognition (SARMAC) is scheduled to take place at Bates College in Lewiston, Maine from July 25, 2007 through July 29, 2007. Bates is a small residential liberal arts college with excellent facilities for hosting the biennial meeting, including a new dormitory for conference guests and a beautiful academic building for conference sessions. Bates is conveniently located 35 miles north of Portland, the largest city in Maine and a tourist hot spot. Bates is also well located for day trips to the stunning rocky Maine coastline (45 minutes) and the foothills of New Hampshire's White Mountains (45 minutes). Please mark your calendars for SARMAC VII and consider combining your conference attendance with an extended stay in the area. For more information about the conference or the area, please contact Amy Bradfield Douglass, adouglas@bates.edu or the Executive Director of SARMAC, Mike Toglia,Toglia@cortland.edu.

\section{Law \& Society Association Annual Meeting, Berlin, July 25-28, 2007}

The Law \& Society Association has released its call for participation in its annual meeting, which this year will be cosponsored by five other sociolegal scholarly associations and will be held in Berlin. We encourage psychology and law scholars to attend this exciting event! The meeting promises to be a very important one for people who are interested in empirical approaches to law and legal systems and want to explore the international and global possibilities of their work. There will be special graduate student activities too, to facilitate the development of international connections among the next group of sociolegal scholars. If you are interested in presenting your work, want some advice about organizing a panel, or just want to learn more about the meeting, you will find full details on the website at http:// www.lawandsociety.org/ann_mtg/am07/call.htm. Please feel free to email Program Committee members Valerie Hans (Valeriehans@lawschool.cornell.edu) and Mona Lynch (mlynch@email.sjsu.edu)with your questions. See you in Berlin!

\section{3rd International Congress of Psychology and Law}

CALL FOR ABSTRACTS Use the following link : http:// www.sapmea.asn.au/conventions/psychlaw2007/index.html and then go to menu button: 'Call for Abstracts'

This will take you straight to the submission facility. Look for the 3rd International Congress of Psychology and Law and 'click here for abstract submission'. Register your details and then a template and instructions will be emailed to you. To register you require your email address and a 'password' nominated by yourself.

\section{Calls for Conferences and Papers}

\section{International Colloquium on Conflict and Aggression (CICA) and the International Society for Terrorism Research (STR)}

We are extremely pleased to announce the first-ever joint meeting of the International Colloquium on Conflict and Aggression (CICA) and the International Society for Terrorism Research (STR), to be held September 28-30, 2007. Please visit our conference website for the official CICA-STR call for papers and details on registering for the conference:

http://societyforterrorismresearch.org/CIC A STRCallforpapersSept2007.html

http://societyforterrorismresearch.org/CICASTRConferenceSept2007.html

Conference Location:

La Cristalera

University of Madrid's Conference Center

Miraflores de la Sierra, Spain

http://www.lacristalera.com/

We invite submissions on all topics related to the brain, aggression, and terrorism. A selection of conference papers will tentatively be published in STR's new Journal of Terrorism Research.

The following are some suggested categories for presentations, others are possible.

- $\quad$ Defining the terms of conflicts

- $\quad$ Societal and personal reactions to terrorism

- $\quad$ Psychological characteristics of the terrorists

- The role of "hearts and minds" in policy making

- Global context of terrorism and aggression

- Biology and evolution of aggression

- Torture

- $\quad$ Systemic approaches to aggression and terrorism

- Vicious cycles of war and conflict

- $\quad$ Suicide and homicide attacks as vehicles for terrorism

- The effect of dialogue on terrorists peacefully

Providing platforms to terrorists to get their message out

· Complex causation of terrorism and aggression

Please visit our website at the links listed above for: 1) conference details; 2) submission instructions; and 3) our contact information. You may also write Samuel Sinclair at jsincl@post.harvard.edu with questions. We look forward to your submissions and seeing you at the conference! 


\section{Calls for Conferences and Papers}
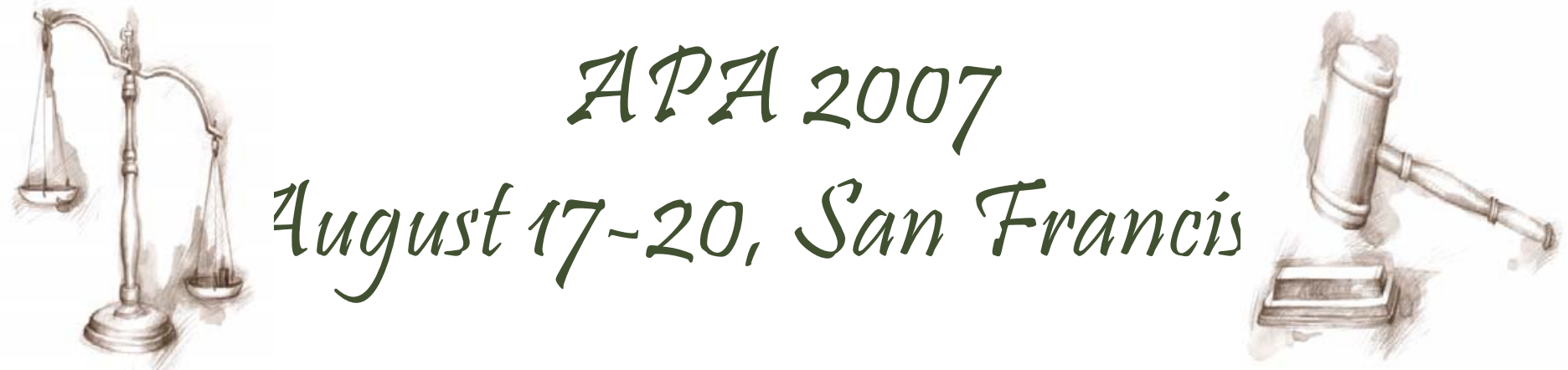

- Division 41 received 147 total proposals this year (58 were received for APA 2006)

- Because of the large increase in submissions, many excellent proposals could not be accepted

Xeeting

highlights:

- Two co-sponsored invited addresses:

- With Division 37 (Child, Youth, and Family Services), and Division 56 (Trauma Psychology)

- Dr. Bruce Perry, author of The Boy Who Was Raised as a Dog

- With Division 3 (Experimental Psychology) - Dr. Steve Clark, UC Riverside

- “The Death Penalty on Trial": mock death penalty sentencing hearing featuring

- expert testimony, attorney arguments, judge's ruting

- "Manifestations of trauma and trauma interventions for justice involving men" presented by the National GAINS Center

FMI contact co-chairs Amy Douglass (adouglas@bates.edu) or Roslyn Caldwell (rcaldwell@jjay.cuny.edu) 


\section{Notes From The Student Chair}

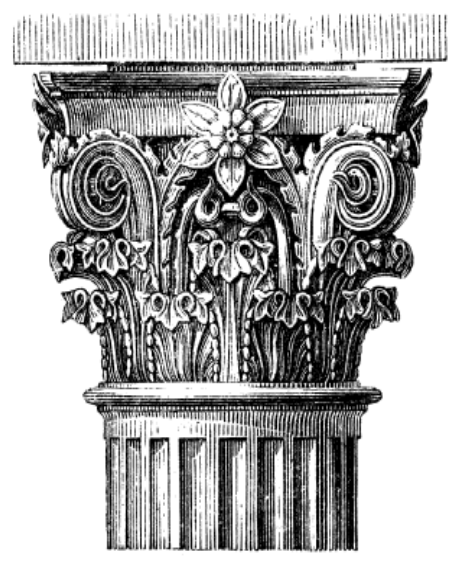

AP-LS Student Officers E-mail Addresses

Chair, Peter Shore phshore@gmail.com

Past Chair, Chris Kunkle cdkunkle@optonline.net

\section{Chair Elect, Andrew Cassens acassens@csopp.edu}

Secretary/Treasurer, David Brillhart dbrillhart@csopp.edu

Student Newsletter/Web Editor, Julie Singer

singerj2@unr.nevada.edu

AP-LS Student Homepage http://www.unl.edu/ap-ls/student/ index.html

AP-LS Student E-mail aplsstudents@yahoo.com

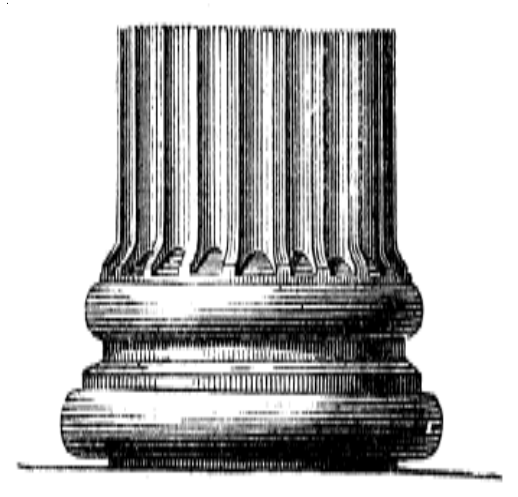

\section{By Peter Shore}

Dear fellow students,

We are continuing to work on the Mentorship program to offer students access to identified specialists in their areas of interest. The focus is professional development in the spirit of assisting the student into a "career."

We need to hear from students first. If you are interested, please email us your top 3 areas of clinical and/or research interests. Secondly, we believe that there could be some role for senior students to act in some sort of mentoring capacity. This happens all the time, informally, of course. Junior students have learned a lot from more senior students. We view this as something to think of as a possible addition to the program. If you are a senior student and wish to mentor junior students, please let us know.

Chair-Elect Andrew Cassens and I have also been working on the following areas:

1) Establish Campus Representative Program for APLS Student Members to foster higher membership rates and greater communication within the field.

2) Involve the Student Executive Committee in Organizational Operations to develop stronger lines of communications with other officers so that we may facilitate more Division growth and effectiveness.

3) Develop a section of the website dedicated solely to master level clinicians working within the forensic community. This would highlight potential job opportunities, offer insight from clinicians working in the field, and contain a discussion board to facilitate conversations between students.

4) Increase student membership and make APLS a more prominent figure within the APA. This will be accomplished by increasing student's understanding of APLS through Campus Representative positions, practitioners appreciation of forensic/legal services through more outreach programs: seminars, lecture series by prominent figures in the field, etc.

We hope Andrew has the opportunity to bring some of these ideas with him well into his term as Chair.

Please stay in touch and let us know if you're interested in getting involved with the mentorship program,

Peter Shore, M.A.

Chair

Andrew Cassens, M.A.

Chair-Elect

E-mail: aplsstudents@gmail.com 


\section{Funding Opportunities}

\section{AP-LS/Division 41 Stipends for Graduate Research}

The Division 41 Grants-in-Aid Committee is accepting proposals for small stipends (maximum of \$750) to support empirical graduate research that addresses psycholegal issues (the award is limited to graduate students who are student affiliate members of AP-LS). Interested individuals should submit a short proposal (a maximum of 1500 words excluding references) in electronic format (preferably Word or PDF) that includes: (a) a cover sheet indicating the title of the project, name, address, phone number, and e-mail address of the investigator; (b) an abstract of 100 words or less summarizing the project; (c) purpose, theoretical rationale, and significance of the project; (d) procedures to be employed; and, (e) specific amount requested, including a detailed budget and (f) references. Applicants should include a discussion of the feasibility of the research (e.g., if budget is for more than $\$ 750$, indicate source of remaining funds). Note that a prior recipient of an AP-LS Grant-in-Aid is only eligible for future funding if the previously funded research has been completed. Applicants should submit proof that IRB approval has been obtained for the project and the appropriate tax form W-9 for US citizens and W-8BEN for international students. Tax forms can be found on the APLS website. Electronic submissions can be submitted via email to Elizabeth Bennett (committee chair): bbennett@washjeff.edu. Tax forms and IRB approval can be FAXed to Dr. Brad McAuliff, Division 41 Treasurer at: 818-677-2829. There are two deadlines each year: September 30 and January 31.

\section{Now Updated: Resource Directory of Forensic Psychology Pre-Doctoral Internship Training Programs}

The APLS Teaching, Training, and Careers Committee is pleased to announce that the newly updated "Resource Directory of Forensic Psychology Pre-Doctoral Internship Training Programs" is now available on-line at the APLS website www.ap-ls.org. This directory includes a listing of U.S and Canadian pre-doctoral internships with forensic rotations including: setting, population, type of forensic assessment and treatment experiences, as well as time spent at each training experience. Email and website addresses have been included to facilitate contact with internship programs. This directory is a must-have for students interested in forensic psychology.

The TCC is indebted to Professor Alvin Malesky and Allison Croysdale for all their efforts spent in updating this directory.

\section{American Academy of Forensic Psychology Dissertation Grants in Applied Law \& Psychology}

The American Academy of Forensic Psychology (AAFP) has made available up to $\$ 5000$ (maximum award is $\$ 1,500$ per applicant) for grants to graduate students conducting dissertations in applied areas of law and psychology, with preference shown for dissertations addressing clinical-forensic issues. Awards can be used to cover dissertation costs such as photocopying and mailing expenses, participant compensation, travel reimbursement, etc. Awards may not be used to cover tuition or related academic fees. Requests submitted in prior years are ineligible.

Applications will be reviewed by a committee of AAFP fellows and grants will be awarded based on the following criteria:

a potential contribution of the dissertation to applied lawpsychology

methodological soundness/experimental design

$\square$ budgetary needs

review of applicant's personal statement

Students in the process of developing a dissertation proposal and those collecting dissertation data as of March 31, 2007 are eligible. To apply, students must submit the following no later than March 31, 2007 (incomplete applications will not be considered):

a letter from the applicant detailing:

his/her interest and career goals in the area of law and psychology

a summary of the proposed dissertation and its time line (no more than 5 pages, double spaced)

a the dissertation budget, the award amount requested, and how the award will be used

a a current CV

a a letter (no longer than one page) from the applicant's dissertation chair/supervisor offering his/her support of the applicant, noting that the dissertation proposal has been or is expected to be approved, and will be conducted as detailed in the applicant's letter

Submit the materials electronically (no later than March 31, 2007) to:

phwitt@optonline.net OR Submit four copies of the above (postmarked no later than March 31, 2006) to:

Philip H. Witt, Ph.D.

Associates in Psychological Services, P.A.

25 N. Doughty Ave.

Somerville, NJ 08876

Questions or inquiries regarding the award competition can be directed to Philip Witt at the above address or via Email at phwitt@optonline.net.

\section{Minority Affairs Committee Awards}

The AP-LS Minority Affairs Committee has several funding awards each year. Please see the Diversity Column on page of this issue for mor information. 


\section{Fellowships and Positions}

\section{Postdoctoral Fellow, Center for Mental Health Services and Criminal Justice Research.}

This center is funded by NIMH and NIDA to develop new researchers in this important area of study. The Center is "borderless," such that candidates could work with mentors in locations other than the Rutgers and Penn campuses, including the University of California, Irvine. Locations must provide sufficient resources for mentoring and collegial support in behavioral health, mental health, substance abuse, and criminal justice research. The training program will begin in September 2007. Priority consideration is given to applications received by March 1, 2007. Please see the following page for details:

http://www.cmhs-cjr.rutgers.edu/html/research/training.htm

You may also contact Jennifer Skeem (skeem@uci.edu ) or Jeffrey Draine (jdraine@sp2.upenn.edu) directly with inquiries.

\section{Postdoctoral Fellowship in Forensic Psychology}

Minnesota State Operated Forensic Services is offering an advanced forensic postdoctoral fellowship beginning September 2007. This fellowship involves extensive training in forensic evaluation and case law. Fellows also complete a Psychiatry and Law course at The William Mitchell College of Law. Stipend of 53K with benefits. Applicants must have successfully completed an APA-accredited internship by September 2007. Interested applicants should send three letters of recommendation, graduate transcripts, curriculum vita, two forensic work samples, and a letter of interest by February 1, 2007 to Dr. Kelly Wilson, Director of Forensic Training, 100 Freeman Drive, St. Peter, Minnesota, 56082-1599. Call Dr. Wilson with any questions at (612) 237-3700, or via e-mail at Kelly.L.Wilson@State.Mn.US

\section{ALBANY COUNTY DEPARTMENT OF MENTAL}

HEALTH is seeking a Psychologist to provide services in the Mental Health Unit located at the Albany County Correctional Facility. This is a unique opportunity to work in a multidisciplinary NCCHC accredited mental health service. The position offers an opportunity to work directly with the criminal justice system to provide court ordered evaluations, treatment, and alternatives to incarceration. Additional components of this position include consultation with correctional and medical staff as well as advocating for the needs of the inmate-consumers. Eligible candidates must posses a NYS License (consideration given to out of state license on limited basis.) The salary is negotiable. Albany County offers an excellent benefits package. Interested candidates please send a cover letter and resume to Susan Daley, Albany County Department of Mental Health, 175 Green Street, Albany, New York 12202

\author{
Post-Doctoral Psychology Positions: \\ North Texas State Hospital
}

The Psychology Discipline of North Texas State Hospital (NTSH), the Texas psychiatric hospital system's only maximum security facility, anticipates two one-year forensic post-doctoral psychology positions, beginning September 1, 2007. Supervised forensic psychological experiences include evaluation, treatment and consultation to multidisciplinary service teams. Populations include co-ed adult and adolescent public psychiatric inpatients. Treatment tracks are structured to meet psychosocial needs within a social learning frame, and are uniquely forensic in orientation. Heavy emphasis is placed on conducting evaluations of trial competence, dangerousness risk, psychodiagnosis and malingering. These render recommendations to assist multidisciplinary teams and finders of fact with relevant disposition decision-making. Individual and group psychotherapies assist with treatment objectives such as competence restoration and violence relapse prevention. Broad exposure to Texas District Courts results from the hospital's prominent role with respect to competence restoration and treatment of insanity acquitees across the state. Opportunities exist to testify at court and to the Department of State Health Services Dangerousness Review Board. Didactic and other learning opportunities enhance intensive case supervision, which is structured to surpass state licensure requirements for post-doctoral supervision. Supervisors are licensed psychologists with considerable forensic training and experience. Competitive salary and excellent benefits. Applicants must hold Ph.D. or Psy.D. from an APA-accredited program. Along with a completed application, please submit a Curriculum Vitae, three sanitized work samples, and a copy of education transcript. Electronic applications for all posted psychologists positions may be obtained at https:// accesshr.hhsc.state.tx.us

For additional information or assistance with the application process, contact:

Michael Jumes, Ph.D.,

Director of Psychology,

North Texas State Hospital

P. O .Box 2231, Vernon, Texas 76384

940-552-4140

michael.jumes@dshs.state.tx.us

\section{Post-Doctoral Fellowship}

Central State Hospital, in Petersburg, VA, announces a one-year postdoctoral fellowship in forensic psychology to begin in July 2007. This fellowship will provide training and supervision in the evaluation and treatment of forensic inpatients, and is designed to meet all requirements for licensure as a clinical psychologist in the state of Virginia. The stipend for this position is $\$ 40,000$, with excellent health and leave benefits. For further information or a copy of the program brochure please e-mail Dr. Rebecca Stredny at rebecca.stredny@csh.dmhmrsas.virginia.gov.

AP-LS NEWS, Winter 2007 


\section{Fellowships and Positions}

\section{Forensic Psychologist}

The Institute of Law, Psychiatry and Public Policy, Department of Psychiatry and Neurobehavioral Sciences, University of Virginia Health System, is looking to recruit a forensic psychologist to serve on the medical faculty. Responsibilities include performing criminal and civil forensic evaluations, initiation of and participation in forensically based research, teaching at the Schools of Law and Medicine, supervision of psychology and psychiatry students, residents, and fellows, and the training of new community based forensic evaluators. A PhD in clinical psychology and substantial experience in forensic evaluations are required. An interest in the blend of clinical practice and research is also required. The position can be filled at either the Assistant or Associate level depending on experience. Salary range $\$ 65,000-\$ 75,000$. The position will remain open until filled.

Please submit your application and the name of three references to: Dr. Eileen Ryan

University of Virginia Health System

Department of Psychiatry \& Neurobehavioral Sciences

P O Box 800623

Charlottesville, VA 22908

E-mail: er3h@virginia.edu

Women and minorities are encouraged to apply. The University of Virginia is and Equal Opportunity/ Affirmative Action Employe.r

\section{Residency Position Available for Fall, 2007}

IBSL is seeking a doctoral resident for the 2007-2008 year. Residents will have a unique opportunity to work in one of the busiest forensic private practices in the country. Opportunities include working on a variety of forensic cases in a private practice setting, gaining experience with a wide variety of psychological testing instruments, observing high profile trials and expert witness testimony, and learning the practical business aspects of running a forensic private practice. For those interested in pursuing a career in forensic psychology, the position also offers a unique opportunity to grow into an associate's position within the practice, particularly for those with specialized forensic interests such as child witness work, domestic violence assessments, forensic neuropsychology, or child custody cases. Please visit our website at www.forensic-experts.net to learn more about our practice.

The ideal applicant will have strong writing skills. Testing experience using standard psychological measures, such as the WAIS, WISC, and MMPI, is necessary. Experience with specialized forensic instruments, such as the PCL-R, TOMM, and VIP, is a plus, but not necessary. Interested students should send a letter of interest, curriculum vitae, and forensic writing sample to: mpbrannon@forensic-experts.net, or mail to: IBSL, 200 SE 6 ${ }^{\text {th }}$ Street, Suite 601, Fort Lauderdale, FL 33301.

\section{Staff Psychologist}

Staff Psychologist position available with the County Forensic Unit of the Albany County Department of Mental Health, Albany, New York. Unique opportunity to be part of a multidisciplinary NCCHC accredited mental health service. Duties include courtordered mental health evaluations and pre-employment psychological evaluation of law enforcement officers, plus clinical treatment of incarcerated individuals with mental illness. Must possess a NYS license. Salary based on experience. Excellent benefit package. Send resume to Susan Daley, Albany County Department of Mental Health, 175 Green Street, Albany, New York 12202 or e-mail to Sdaley@albanycounty.com

\section{Employment Opportunities for Clinical and Counseling Psychologists at Florida State Hospital}

Florida State Hospital is Florida's largest and oldest mental health facility. We seek 5 full-time psychology staff for positions in: Forensic and Forensic Transition. Florida State Hospital employs 35 doctorate and 11 master's psychology staff, trains 7 persons per year, and is a major university externship site. Nearly all emotional and character-ological disorders are encountered here. Hospital residents are men and women ranging in age from teens to octogenarians. Major programming areas include admissions, acute care, forensic, forensic transition, developmental disabilities, gerontology, diversified care, and quarterway house. Residents are committed by state circuit courts as incompetent to proceed to trial, not guilty by reason of insanity, and involuntary civil. Some residents of Civil Service treatment units are voluntary admissions. Psychology staff at Florida State Hospital provide essential services in multiple areas: assess need for continued hospitalization and competency to proceed to trial, provide psychological assessment, evaluate dangerousness, conduct individual and group psychotherapy, develop psycho-social and behavioral interventions, consult with ward staff and unit management, provide reports and testimony to committing courts, and supervise psychology interns, and postdoctoral psychology residents. Psychologists work as members of unit-based interdisciplinary teams. Research is encouraged within the requirement that direct service is the primary priority.

Doctoral Positions require a doctoral degree from an APA-accredited clinical or counseling program and an APA-accredited internship. Salaries depend upon training, experience and licensure, with usual starting salaries from $\$ 40,000$ to $\$ 60,000$. As a public employee, you will receive annual leave and sick leave, enrollment in health insurance, and participation in the state retirement system after six years employment. Unusually well qualified persons with master's degrees, and pre-dissertation doctoral students before or after internship, may be considered for some positions.

Doctorate holders without supervision for licensure are automatically enrolled in the hospital post-doctoral residency program. Specialized forensic instruction is provided to psychology staff whose training and experience in this area is limited.

Interested persons can contact Lawrence V. Annis, Ph.D., Psychological Services Director at Larry_Annis@dcf.state.fl.us. Florida State Hospital is an Affirmative Action/Equal Opportunity Employer and encourages applications from women and minorities. 


\section{Conference and Workshop Planner}

American Psychological

Association Annual Meeting

August 16 - 19, 2007

San Fransisco, California

Submission deadline: 12/01/06

For further information see www.apa.org/conf.html

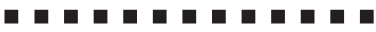

Law and Society Association

Annual Meeting

July 25 - 28, 2007

Berlin, Germany

Submission deadline: 1/12/07

For further information see

www.lawandsociety.org

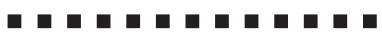

3rd International Congress of

Psychology and Law

July 3- 8, 2007

Adelaide, Australia

For further information see www.sapmea.asn/conventions/

psychlaw2007/index.html

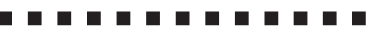

International Association of

Forensic Mental Health

Annual Meeting

June 26 - 28, 2007

Le Centre Sheraton

Montreal, Canada

Submission deadline: $2 / 15 / 07$

For further information see

www.iafmhs.org/iafmhs.asp
The next American Psychology-

Law Society

Annual Meeting

March 5 - 9, 2008

Jacksonville, FL

Mark it on your calanders!!

For further information see www.ap-ls.org

Society for Applied Research in

Memory \& Cognition

July 25-29, 2007

Bates College

Lewiston, Maine

For further information see www.sarmac.org

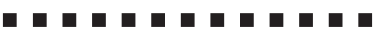

Association for

Psychological Science

Annual Convention

May 24 - 27, 2007

Washington, DC

For further information see www.psychologicalscience.org

American Society of Criminology

November 14 - 17, 2007

Millenium Biltmore Atlanta, GA

For further information see www.asc41.com

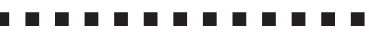

American Psychological Association Annual Meeting

August 14 - 17, 2008 Boston, MA

For further information see www.apa.org/conf.html
American Academy of Forensic Psychology

Contemporary Issues in

Forensic Psychology

March 21-55, 2007

Ritz Carlton, Montreal

Montreal, Quebec, CA

For further information see www.aafp.ws

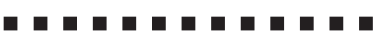

American Academy of Forensic

Psychology

Contemporary Issues in

Forensic Psychology

April 25-29, 2007

Hyatt Regency Newport Hotel and Spa

Atlanta, GA

For further information see www.aafp.ws

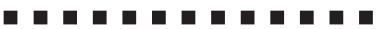

American Academy of Forensic Psychology

Contemporary Issues in Forensic Psychology

May 30-June 3, 2007

Embassy Suites Ft. Lauderdale

Ft. Lauderdale, FL

For further information see www.aafp.ws

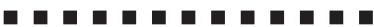

Note: The American Academy of Forensic Psychology will continue to present workshops throughout 2006-2007

Dates and Locations will be available at www.abfp.com

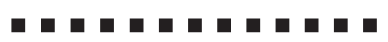

Information regarding upcoming conferences and workshops can be sent to Jennifer Groscup (jgroscup@jjay.cuny.edu) 


\section{Grant Writing Planner}

\section{National Science Foundation}

Law and Social Sciences Division

Submission deadlines:

January 15th and August 15th, yearly

For further information see www.nsf.gov

National Science Foundation

Law and Social Sciences Division

Dissertation Improvement

Grants

Submission deadlines:

January 15th and August 15th, yearly

For further information see www.nsf.gov

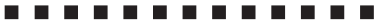

American Psychological

Association

Various awards compiled by the APA are available for psychologists

Submission deadlines: Various

For further information see www.apa.org/psychologists/ scholarships.html

Society for the Psychological

Study of Social Issues (SPSSI)

Grants-in-Aid

Maximum awards:

Graduate Student: \$1000

PhD Members: \$2000

Submission deadlines:

May 1, 2007 \& October 1, 2007

For further information see www.spssi.org
American Psychological

Association

Dissertation Awards

Submission deadline:

September 14, 2007

For information see

www.apa.org/science/dissinfo.html

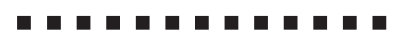

Association for

Psychological Science

Travel Assistance Competition

Travel awards for the

APS Annual Convention

Submission deadline: Mar. 31, 2007

For further information see www.psychologicalscience.org

National Institute of Justice Grants to reduce domestic violence, dating violence, sexual assault, and stalking on campus

Submission deadline:

March 8, 2007

For information on NIJ funding for research on the criminal justice system see www.ojp.usdoj.gov/nij

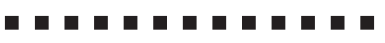

American Psychological Association

Student Travel Awards

Travel awards for the 2007 Annual Convention

Submission deadline: April 2, 2007

For further information see www.apa.org/science/ travinfo.html:
American Psychology-Law

Society Grants-in-Aid

Maximum award: $\$ 500$

Submission deadlines:

January 31st and September 30th, yearly

For further information see page 39

American Psychological Association

Student Early Researcher Award 2007

Submission deadline: late 2007

For further information see www.apa.org/science/era.html

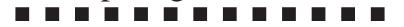

American Psychological Association

Student Awards

Various awards compiled by the APAGS are available for students

For further information see www.apa.org/apags/members/ schawrds.html:

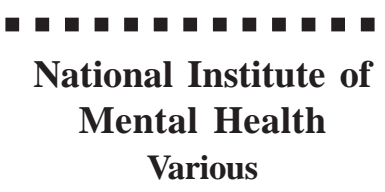

Submission deadline: Various

For information on NIMH funding for research on mental health see www.nimh.gov

Information regarding available grants and awards can be sent to Jennifer Groscup (jgroscup@jjay.cuny.edu) 